\title{
IZ ANTOLOGIJE TEHNOLOGIJSKOG PRAVA: AUTONOMNI BROD I DRUGI NAPREDNI OBJEKTI U NOVOM POMORSKOM ZAKONIKU - DE LEGE PONDERANDA ${ }^{2}$
}

\author{
UDK: $347.79: 629.51 / .58(497.5)$ \\ DOI: $10.31141 /$ zrpfs.2021.58.141.875 \\ Pregledni rad \\ Primljeno: 1. listopad 2020
}

\begin{abstract}
S ciljem da se hrvatsku zastavu učiniti atraktivnom za strana plovila, hrvatski zakonodavac donio je dana 8. veljače 2019. g. Odluku o proglašenju zakona o izmjenama i dopunama Pomorskog zakonika - kao dio reformskog paketa pomorskog zakonodavstva. Pored izmjena vezanih uz upisnik, konkretno njegovu digitalizaciju i objedinjavanje podataka, izmjene uključuju i normiranje ugovora o najmu jahte i brodice, zatim rješenja vezana za sprečavanje onečišćenja mora, kao i rješenja s područja pomorskog radnog prava. Međutim, izvršene su i određene izmjene pomorskopravne nomenklature među kojima je i uvođenje nove pravne kategorije autonomnog plovnog objekta. U ovom radu analizira se stoga položaj takvog objekta u okviru aktualnog pomorskog zakonodavstva Republike Hrvatske te se razmatra daljnji smjer kretanja u vidu de lege ferenda osobito kada su u pitanju autonomni brodovi. U radu se razmatra je li uvođenjem nove pravne kategorije Pomorski zakonik otvoreno prepoznao autonomne brodove i u kojem opsegu. Uz ovo, rad također uključuje uvođenje nove (dodatne) klasifikacije s obzirom na nova tehnološka dostignuća i trendove, a koja preporuka se nadograđuje direktno na postojeću pomorskopravnu nomenklaturu, nudeći prikladno nomotehničko rješenje u uređenju novih vrsta objekata uopće, bez zadiranja stanovitim zahvatima u postojeći sadržaj Pomorskog zakonika kako je koncipiran.
\end{abstract}

Ključne riječi: autonoman plovni objekt, Pomorski zakonik, autonomni brod, napredni pomorski objekti, autonomno brodarstvo, tehnologijsko pravo, pomorsko pravna nomenklatura

\section{UVOD}

Autonomna prijevozna sredstva postaju sve atraktivniji fenomen, a među njima posebice plovni objekti. Autonomne ronilice već neko vrijeme pronalaze svoju

1 Moreno Pajković, magistar prava s položenim pravosudnim ispitom, HR-51000 Rijeka, e-mail: mpajkovic.mi@outlook.com.

2 Rad predstavlja svojevrstan nastavak na autorov rad i istraživanje provedeno u projektu pravne $\mathrm{i}$ društvene analize tzv. "brodova dronova" od 2016., a u povodu interesa iskazanog od strane Sindikata pomoraca Hrvatske (SPH). 
Moreno Pajković, mag. iur.: Iz antologije tehnologijskog prava: autonomni brod i drugi napredni objekti...

Zbornik radova Pravnog fakulteta u Splitu, god. 58, 3/2021, str. 875-906

primjenu u različite svrhe (npr. istraživačke), dok autonomna površinska plovila, konkretno autonomni brodovi privlače sve veću pozornost.

Premda je prema prvotnim planovima 2018. trebala biti godina kada norveška kompanija Yara Birkeland u funkciju pušta prvi visoko automatizirani kontejnerski brod, koji je već do 2019. trebao biti daljinski upravljiv, ${ }^{3}$ primjeri preteče autonomnog brodarstva danas ipak već postoje. Naime, pored prvog autonomnog ratnog broda Sea Hunter stvorenog u okviru programa ACTUV ${ }^{4}$ suradnjom mornarice Sjedinjenih Američkih Država i agencije DARPA još 2016. g., postoji i nešto raniji primjer vrijedan spomena, a to su flota autonomnih plovila američke kompanije SpaceX. ${ }^{5}$ Prvi pod imenom "Just Read the Instructions" u Tihom oceanu i drugi "Of Course I Still Love You" u Atlantskom oceanu, oba autonomna plovna objekta zapravo su mobilne platforme za slijetanje raketa iz orbite, a poznati su kao Autonomous Spaceport Drone Ship (ASDS). ${ }^{6}$ Osim ovih, postoje i nešto recentniji primjeri autonomnih plovnih objekata znanstvenoistraživačke kategorije tzv. C-Worker 7 kompanije ASV Global, i to kao prvo takvo plovilo upisano u Upisnik brodova Ujedinjenog Kraljevstva (dalje: UK). ${ }^{7}$

Dok su planovi norveške Yare redefinirani novim razvojnim fazama, koji realizaciju prvotne zamisli predviđaju u prvom kvartalu 2020. g. s 2021. kao godinom kada bi visoko automatizirani kontejnerski brod trebao ući u tranzicijsku fazu kao autonoman s nadzorom iz kontrolnog centra na kopnu, a nakon toga do 2022. g. bi trebao postupno postati potpuno automatiziran, odnosno autonoman ${ }^{8}-$ rasprave na tehničkom, društvenom, organizacijskom i regulatornom planu postaju sve aktualnije.

Neke su studije i projekcije već izrađene, a izrada nekih drugih još je u tijeku i to na različitim razinama, od regionalnih do međunarodnih, $u$ privatnom i javnom sektoru involviranošću različitih sudionika iz područja industrije, tj. poduzetništva, znanosti i obrazovanja te državne administracije, odnosno regulatornih tijela. Dok se u međuvremenu nude različite smjernice i preporuke, Republika je Hrvatska (dalje: RH) u okviru najnovijih izmjena i dopuna svoga corpus iuris maritimi u

3 Ćorić, D.; Pajković, M., "Autonomni brod - nova vrsta broda u pomorskom zakonodavstvu", Zbornik radova 2. Međunarodne znanstvene konferencije iz pomorskog prava - Suvremeni izazovi pomorske plovidbe (ISCML), Pravni fakultet Sveučilišta u Splitu, Split, 2018., str. 107.

4 Anti-Submarine Warfare Continuous Trail Unmanned Vessel.

5 Isto: Vojković, G.; Milenković, M., "Autonomous ships and legal authorities of the ship master", Case Studies on Transport Policy, https://doi.org/10.1016/j.cstp.2019.12.001, p. 3.

6 The Planetary Society, Davis, J., Of Course I Still Love You, Falcon: New SpaceX Ship Ready to Catch Rockets,http://www.planetary.org/blogs/jason-davis/2015/20150625-of-course-i-still-love-you. html?referrer=https://www.google.hr/ (20. VII. 2016.).

7 Dean, P.; Walters, T.; Goulding, J., Autonomous Vessels - Are regulations keeping up with innovation?, HFW Briefings, Shipping, https://www.hfw.com/Autonomous-vessels-are-regulationskeeping-up-with-innovation-November-2017, November 2017, p. 2.

8 Autonomous ship 'Yara Birkeland' - how far has the industry reached?, https://www.dnmf.no/ Artikler/SiteAssets/Sider/Arbeidet-i-ITF-med-autonome-skip/Autonomous\%20ship\%20Yara\%20 Birkelnad\%20how\%20far\%20has\%20the\%20industry\%20reached.pdf (9. III. 2019.). 
pomorskopravnu nomenklaturu uvela novu kategoriju plovila - autonomni plovni objekt. $^{9}$

\subsection{Cilj, struktura i metodologija rada}

Kako to biva s novom tehnologijom, postavlja se uvijek pitanje kako se ona uklapa u dosadašnje poznate okvire društva. Naime, sa svojim razvojnim potencijalom i transformativnom snagom, inovacije i tehnologija, a osobito ona nova i revolucionarna, stvaraju nove setove problema i dilema koji sežu od etičkih pitanja preko institucionalnih i organizacijskih do onih praktičnih i aplikativnih. ${ }^{10}$ Pritom, neposredno utječe na društvenu zbilju, mijenjajući je pa barem inkrementalno, dok neke od njih imaju snagu u potpunosti promijeniti našu paradigmu.

Naime, nakon interneta, daljnji razvoj tehnologije umjetne inteligencije (dalje: UI), tzv. "četvrta industrijska revolucija" nagovijestila je dolazak samoupravljajućih prijevoznih sredstava, a nakon toga i sve efikasnijih vrsta robota. Povrh toga, i nova kriptografska metoda, točnije tzv. blockchain tehnologija došla je kao dodatno gorivo u ovako već dinamičan teren. Uslijed takvih i drugih sličnih inovativnih iskoraka, slijedi često i pitanje: "je li legalno" (engl. is it legal)?

Stoga se u pokušaju da novi tehnološki fenomen bude izvediv u zbilji, nastoje pružiti odgovori u pravcu postojećih pravnih pravila i standarda te uklopljenosti tehnološkog dostignuća unutar tog pravnog, ali društvenog okvira. Tu raspravu prati i evaluacija eventualne potrebe za mijenjanjem postojećih pravila i standarda, odnosno stvaranju pak novih. Sve to objedinjeno je tzv. tehnologijskim pravom, a otud često i pravnom futurologijom.

Izlažući hipotezu i metodologiju rada, u nastavku se stoga usputno definira i pojam tehnologijskog prava s obzirom na to da se dijelom dotiče i njemu svojstvene metode (više infra).

Slijedom navedenog, ideja ovog rada jest prezentirati novouvedenu pravnu kategoriju autonomnog plovnog objekta i analizirati položaj istog u kontekstu aktualnog hrvatskog pomorskog prava. Na tom tragu, razmotrit će se pravni učinci koje takva pravna kategorija za sobom povlači, odnosno aplikativnost samih propisa uslijed uvođenja autonomnog plovnog objekta kao pravnog pojma. U tom

9 Nasuprot hrvatskom primjeru, u zakonodavstvu Republike Koreje (Južne Koreje), primjerice, postoji Zakon o promicanju distribucije i razvoju inteligentnih robota (engl. Intelligent robots development and distribution promotion act) iz 2008., izmijenjen i dopunjen 2016., koji u čl. 2., st. 1. predviđa zakonsko određenje termina inteligentnog odnosno "pametnog robota" (engl. intelligent robot), a definira ga kao: "mehanički uređaj koji percipira vanjsko okruženje samostalno, razlučuje okolnosti i kreće se dobrovoljno." [Ministry of Trade, Industry and Energy, Act No 13744, 6th January 2016].

10 Isto: Marchant, G. E., "The Growing Gap Between Emerging Technologies and the Law", The Growing Gap Between Emerging Technologies and Legal-Ethical Oversight: The Pacing Problem, Springer Netherlands, 2011., p. 19; Vidi isto: Robinson, W. K., "Emerging Technologies Challenging Current Legal Paradigms", Minnesota Journal of Law, Science \& Technology, Vol. 19, No. 2, 2018., pp. 356-358. 
smislu, posebno će se u fokusu imati pitanje je li takvim zahvatom u pomorsko zakonodavstvo prepoznat autonomni brod i njegove različite varijante.

Slijedom toga, ukazat će se na prednosti, ali i na potencijalne nedostatke uvođenja nove pravne kategorije, a kako trenutno stanje po autorovu mišljenju dovodi i do neizravnog prepoznavanja autonomnog broda, u radu će se preporučiti i eventualna alternativna rješenja. Povrh toga, ponudit će se i rješenja de lege ferenda osobito kada se uzme u obzir postojanje i drugih naprednih pomorskih objekata.

Kao rad koji se u središtu svog razmatranja bavi pravnom refleksijom nove i potencijalno transformativne tehnologije, ujedno se želi doprinijeti i osnaživanju hrvatskog korpusa literature tehnološkog $\operatorname{prava}^{11}$ i pravne futurologije čime se istovremeno doprinosi i domeni pravne znanosti koja se bavi novim tehnologijama i tehnologijama u nastajanju (engl. New and Emerging Technologies - NET). ${ }^{12}$

\subsubsection{Tehnologijsko pravo}

Uz tehnološku revoluciju koja se uistinu munjevito odvija, poteškoće u održavanju koraka s njom nisu začuđujuće, a kako se razdor koji ona stvara održava na sve sfere društva pa tako i prava, reaktivan pristup prava razumljiva je posljedica takvih zbivanja. ${ }^{13}$

Premda se može reći kako se tehnologijsko pravo u prvom redu bavi različitim pitanjima skupljanja, pohranjivanja, korištenja i diseminacije digitalnih podataka, njegov se opseg neupitno mijenja te se neprestano proširuje. Tako se ono često izjednačava s "IT ili ICT ${ }^{14}$ pravom", iako je bolje reći da ga tehnologijsko pravo objedinjuje, jednako kao što se može reći da objedinjuje tzv. "internetsko pravo", zatim digitalno pravo, u zadnje vrijeme blockchain pravo, ${ }^{15}$ pa čak i tzv. "robotsko pravo"16 kao koncept u povojima. Međutim, ono jednako kao i sportsko pravo ili medicinsko pravo donekle zahvaća skup više rascjepkanih manjih ili većih zasebnih

11 Primjerice; Dragičević, D., Pravna informatika i pravo informacijskih tehnologija, Narodne novine, 2015.; Luttenberger, A.; Kos, S., "A Proposal for a GNSS Failure Legal Liabilities Scheme", 6th GNSS Vulnerabilities and Solutions Conference, Rijeka, Faculty of Maritime Studies, University of Rijeka, Croatia; The Royal Institute of Navigation, London, UK; The Nottingham Geospatial Institute, University of Nottingham, UK, 2013., pp. 77-87, https://www.bib.irb.hr/625386, (16. V. 2019.); Vojković, G.; Milenković, M.; Vojković, L., "Odgovornost pri korištenju bespilotnog zrakoplova s broda", Zbornik radova 1. Međunarodne znanstvene konferencije iz pomorskog prava - Suvremeni izazovi pomorske plovidbe (ISCML), Pravni fakultet Sveučilišta u Splitu, Split, 2017., str. 465-474.

12 Vidi više o tehnologijskom pravu: Lexis PSL TMT Team, An Introduction to Technology Law, LexisNexis UK, 2018; Murray, A., Information Technology Law - Law \& Society, Oxford University Press, 2019.

13 Bainbridge, D., Introduction to Information Technology Law, Longman; 6th edition, 2007, p. 1.

14 Informacijske tehnologije ili informacijsko-komunikacijske tehnologije. 2018.

15 De Filippi, P.; Wright, A., Blockchain and the Law: The Rule of Code, Harvard University Press,

16 Vidi: Calo, R.; Froomkin, A. M.; Kerr, I., Robot Law, Edward Elgar, 2016.; Chopra, S.; White, L. F., A Legal Theory for Autonomous Artificial Agents, University of Michigan Press, 2011.; vidi također: Rezolucija Europskog parlamenta od 16. veljače 2017. s preporukama Komisiji o pravilima građanskog prava o robotici (2015/2103(INL)). 
Moreno Pajković, mag. iur.: Iz antologije tehnologijskog prava: autonomni brod i drugi napredni objekti... Zbornik radova Pravnog fakulteta u Splitu, god. 58, 3/2021, str. 875-906

područja, manje ili veće kompleksnosti, ili se pak koncentrira na tek pojedina pitanja već etabliranih grana prava pristupajući im sa svog kuta gledišta.

Tako tehnologijsko pravo dotiče pojedina pitanja prava ljudskih prava, točnije prava privatnosti, zatim sve aktualnije pravo osobnosti, odnosno pravo publiciteta, nadalje ugovorno pravo pa i pravo izvanugovornih odnosa, tj. odgovornosti za štetu. Uz ovo, tu su svakako i pravo intelektualnog vlasništva, ${ }^{17}$ kazneno pravo, točnije posebna kaznena djela ${ }^{18}$ pa čak i dokazno pravo, tj. pravila koja uređuju dokazivanje činjenica u pravnim postupcima. ${ }^{19}$

Tehnologijsko pravo u fokusu svoga razmatranja tako uključuje različite digitalne, tehničko-tehnološke i inovativne pojave poput velikih skupova podataka (engl. Big data), ${ }^{20} \mathrm{P} 2 \mathrm{P}$ platforme ${ }^{21}$ (npr. Click\&Boat, Boatsetter, Mooringo i dr.), ${ }^{22}$ elektroničku razmjenu podataka, ${ }^{23}$ a otud primjena blockchain tehnologije i platforma (npr. ShipChain, Insurwave i dr.), ${ }^{24}$ zatim obalnu opskrbu brodova električnom energijom, ${ }^{25}$ ali i svako drugo manje ili veće unapređenje u tehnologiji ${ }^{26}$ - primjerice u pomorskoj industriji - poput sustava za čišćenje ispušnih plinova (engl. Scrubber), sustava za daljinsko upravljanje brodskim kontejnerom (engl. Remote Container Management - RCM ${ }^{27}$ i dr., a među njima i autonomne brodove. Svaki prethodno navedeni fenomen ima nekakav doticaj s pravom. U tom pogledu, odnos navedene tehnologije i prava održava se bilo u vidu jednostranog ili uzajamnog utjecaja jedno na drugo. Dakle, može biti riječ o suglasju između postojećih propisa i tehnologije,

17 Vidi više: Lloyd, I. J., Information Technology Law, Oxford University Press, 6th edition, 2011.

18 Vidi primjerice: Pavlović, Š., "Kompjutorska kaznena djela u kaznenom zakoniku - osnove hrvatskog informacijskog kaznenog prava", Hrvatski ljetopis za kazneno pravo i praksu, vol. 10, br. 2, Zagreb, str. 625-664; ili u pomorskom kontekstu: Rukavina, B., "Kaznenopravna zaštita podmorskih kabela i cjevovoda u međunarodnim konvencijama i nacionalnom zakonodavstvu", Pomorski zbornik, vol. 38., br. 1., str. 191-199.

19 Primjerice u odnosu na uređaj za zapis plovidbenog putovanja, vidi više: Brown, J. T.; Crew, P. N., Voyage Data Recorders - "CSI on the High Seas", presentation at Southeastern Admiralty Law Institute (SALI) meeting in June 2010, republished in Benedict's Maritime Bulletin, and Steamship Mutual's Bulletin, dostupno na: https://www.steamshipmutual.com/publications/Articles/VDRPaper0111.htm (25. I. 2020.); vidi isto: Van Hooydonk, E., The law of unmanned merchant shipping-an exploration, Lawtext publishing limited, 20 JMIL, 2014., p. 415.

20 Vidi više o Big data u pomorstvu: Obradović, I.; Miličević, M.; Maris, M., "Big Data in the Maritime Industry", Naše more, Vol. 65, No. 1, 2018., pp. 56-62.

21 Vidi više: Lobel, O., "The Law of the Platform", Minnesota Law Review, 2016., pp. 87-166.

22 Uber, Bolt, Airbnb kao najpoznatiji primjeri.

23 Vidi: Goldby, M., Electronic Documents in Maritime Trade: Law and Practice, OUP Oxford, 2nd edition, 2019.

24 Vidi više: Jugović, A.; Bukša, J.; Dragoslavić, A.; Sopta, D., The Possibilities of Applying Blockchain Technology in Shipping, Pomorstvo, Vol. 33, No. 2, 2019., pp. 274-279.

25 Primjerice, Preporuka Komisije 2006/339/EZ od 8. svibnja 2006. o poticanju uporabe električne energije s obale za brodove na vezu u lukama Zajednice (SL L 125, 12. V. 2006.).

${ }_{26}$ Vidi primjerice primjenu prava kada su u pitanju posebni oblici pomorskih prijevoznih sredstava: Seršić, V., "Primjena pomorskih propisa na objekte koji nisu plovni objekti u užem smislu", Zbornik radova 2. Međunarodne znanstvene konferencije iz pomorskog prava - Suvremeni izazovi pomorske plovidbe (ISCML), Pravni fakultet Sveučilišta u Splitu, Split, 2018., str. 309-332 in extenso.

27 Vidi: UKP\&I, Hastings, A., What is RCM and what legal considerations does it give rise to?, dostupno na: https://www.ukpandi.com/knowledge-publications/article/legal-update-what-is-rcm-andwhat-legal-considerations-does-it-give-rise-to-145744/ (15. XII. 2019.). 
Moreno Pajković, mag. iur.: Iz antologije tehnologijskog prava: autonomni brod i drugi napredni objekti.. Zbornik radova Pravnog fakulteta u Splitu, god. 58, 3/2021, str. 875-906

zatim može biti riječ o suprotstavljanju tehnologije propisanim pravilima što izražava potrebu za deregulacijom. Nadalje, tehnologija može stvoriti ili razotkriti neke nove pravne praznine, ili pak biti sasvim izvan dometa propisa kao neregulirana materija za koju je potrebno stvoriti nove standarde. Uz ovo, tehnologija otvara i neke nove mogućnosti regulacije, poput adaptacije nekog "mekog prava" (engl. soft law $)^{28}$ - kao već uhodane i poznate mogućnosti - čak do razvijanja nekih novih avangardnijih pristupa poput algoritamskog reguliranja određenih odnosa i situacija tzv. "kodiranim (programskim) pravom" (engl. "Code is law, law is Code") ${ }^{29}$ pa sve do možda nekog, u perspektivi, dalekog "metaprava" (engl. metalaw). ${ }^{30}$

Konačno, osim razmatranja tehnologije momento praesenti - kao što se moglo dosad prepoznati - razmatranje tehnologije moguće je i pro futuro, razvijajući na temelju smjera razvoja tehnologije ili različitih trendova, čak i nešto dalekosežnije projekcije o potencijalnoj refleksiji tehnologije u perspektivi, ali i pristupanju njezinu proaktivnom pravnom adresiranju. ${ }^{31}$ Stoga tehnologijsko pravo često ima tendenciju zalaziti i u sferu pravne futurologije ${ }^{32}$ i poprimati neke njezine elemente. Jedan je takav pristup pravu de lege ponderanda.

Pristup pravu de lege ponderanda ili lex ponderanda, u prijevodu znači "spekulativno pravo" (engl. probing law, speculating law), a označava spekulativnu

28 Hagemann, R.; Huddleston, J.; Thierer, D. A., "Soft Law for Hard Problems: The Governance of Emerging Technologies in an Uncertain Future", Colorado Technology Law Journal, Vol. 17, No. 1, 2018., pp. 37-129; Također: Marchant, G. E.; Allenby, B., "Soft law: New tools for governing emerging technologies", Bulletin of the Atomic Scientists, Vol. 73, No. 2, 2017., pp. 108-114.

29 Vidi više: Lessig, L., Code: And Other Laws of Cyberspace, Version 2.0, Basic Books; 2nd revised edition, 2006.; Vidi također: Brownsword, R., "In the year 2061: from law to technological management", Law, Innovation and Technology, Vol. 7, No. 1, 2015., pp. 1-51.

30 Koncept "metaprava" primarno se veže uz svemirsko pravo i mogućnosti koje potencijalno nastaju prodiranjem čovječanstva u prostranstva svemira, njegovim postupnim širenjem te komercijalizacijom svemira i njegovih resursa. Koncept označava cjelokupni skup pravnih pravila koja reguliraju odnose između različitih rasa u svemiru. Vidi više u: Haley, A. G., "Space Law and Metalaw - Jurisdiction Defined", Journal of Air Law and Commerce, Vol. 24, No. 3, 1957., pp. 286-303; također s tim u vezi: Brumberg, B., "Regulating Private Space Transportation", Administrative Law Review, Vol. 36, No. 4, 1984., pp. 363-385; von der Dunk, F. G., "Space Tourism, Private Spaceflight and the Law: Key Aspects", Space Policy, Vol. 27, No. 3, 2011., pp. 146-152.

31 Primjerice po pitanju primjene blockchain tehnologije u financijskim transakcijama može se navesti nacrt tzv. Blockchain zakona, odnosno Zakona o transakcijskim sustavima koji se temelje na pouzdanim tehnologijama Kneževine Lihtenštajn; vidi više: landesverwaltung fürstentum liechtenstein, https://bua.regierung.li/BuA/default.aspx?nr=54\&year=2019\&erweitert=true (15. XII. 2019.).

32 Vidi više: Funk, D. A., "Legal Futurology: The Field and its Literature", Law Libary Journal, Vol. 73, 1980., pp. 625-628; također: Muller, S.; Zouridis, S.; Frishman, M.; Kistemaker, L. (Ed.), The Law of the Future and the Future of Law, Torkel Opsahl Academic Epublisher (TOAEP), Oslo, 2011.; Također: Muller, S.; Zouridis, S.; Frishman, M.; Kistemaker, L. (Ed.), The Law of the Future and the Future of Law: Volume II, Torkel Opsahl Academic Epublisher (TOAEP), Den Haag, 2012.; vidi isto primjerice: The Future of International Courts and Tribunals: What Developments and Models Will We See in 20 Years?, Brandeis Institute for International Judges (BIIJ), The International Rule of Law in a Human Rights Era, 2013., pp. 34-38, dostupno na: https://www.brandeis.edu/ethics/pdfs/internationaljustice/biij/ BIIJ2013.pdf (15. II. 2020.); Law scenarios to 2030, Hague Institute for the Internationalisation of Law (HiiL), 2012., dostupno na: https://www.hiil.org/projects/law-scenarios-to-2030/ (15. II. 2020.). 
kritičku analizu prava. ${ }^{33}$ Ovo predstavlja relativno novi vid pristupa, kao dodatak dobro poznatim i uhodanim pristupima de lege lata ili lex lata i de lege ferenda ili lex ferenda. Spomenuti pristup primijenjen je u švedskoj antologiji o pravu i informatičkoj tehnologiji, točnije u izvještaju koji je sačinio Opservatorij za informatiku Śvedske komisije za ICT, a pristupom se nastojalo ne samo biti u koraku s tehnologijom, već joj doskočiti na način da se sagledava unaprijed, dakle proaktivno. $^{34}$

$\mathrm{S}$ obzirom na to da je u radu riječ o normativnom uvođenju najnovije (a donekle i eksperimentalne) vrste tehnologije u okvire de lege lata, pravno razmatranje predmetne tehnologije u ovom radu provest će se uz sporadičnu primjenu futurološke metode procjenjujući moguće refleksije u perspektivi, ali i razmatranje de lege ponderanda.

Kako se istaklo in fine 1. 1., autor je mišljenja da je uvođenje autonomnog plovnog objekta u hrvatsku pomorskopravnu nomenklaturu neizravno omogućilo prepoznavanje autonomnog broda. No, uvođenjem nove pravne kategorije izazvani su i dodatni učinci koji se mogu ocijeniti kao nepoželjni pa se postavlja pitanje koji je ratio uvođenja novog pojma.

\section{TEHNOLOGIJA AUTONOMNIH POMORSKIH SUSTAVA - KONCEPTUALNI OSVRT}

\subsection{Općenito}

Autonomni brodovi dio su šireg koncepta tzv. "bespilotnih (autonomnih) $)^{35}$ maritimnih (pomorskih) sustava" (engl. Unmanned Maritime Systems - UMS). Taj opći pojam predstavlja viši rodni pojam u odnosu na autonomne brodove i sve druge objekte s takvom ili sličnom integriranom tehnologijom, a prema grupi SARUMS ${ }^{36}$ općenito se dijeli na:

(a) bespilotna podvodna vozila (engl. Unmanned Underwater Vehicles - UUV)

33 Seipel, P., Law and Information Technology Swedish Views, An anthology produced by the IT Law Observatory of the Swedish ICT Commission, Information and Communication Technology Commission Report, Stockholm, 2002., p. 16; Također: Greenstein, S., Our Humanity Exposed, Predictive Modelling in a Legal Context, Stockholm University 2017., p. 32.

34 Seipel, P., op. cit., u bilj. 31, p. 16; Usputno, s obzirom na same po sebi vrlo indikativne elemente proaktivnosti, moglo bi se slobodno zaključiti da je metoda i općenito svojevrstan odraz proaktivnog pravnog pristupa (engl. proactive law). Tipičan za "nordijsku pravnu školu" budući da je i razvijen u Finskoj još kasnih 1990-ih. Vidi više o proaktivnom pravnom pristupu: Berger-Walliser, G., "The Past and Future of Proactive Law: An Overview of the Development of the Proactive Law Movement", PROACTIVE LAW IN A BUSINESS ENVIRONMENT, Gerlinde Berger-Walliser and Kim Østergaard (eds.), DJØF Publishing, 2012., pp. 13-31.

35 Vidi više o autonomnosti kao stupnju samostalnog djelovanja infra. 2. 1. 2.

36 Grupa SARUMS (Safety and Regulations for European Unmanned Maritime Systems) imala je za cilj organizirati i dokumentirati informacije o tehnologiji, sigurnosti, pravilima i propisima za tzv. bespilotne maritimne sisteme. 
(b) bespilotna površinska vozila (engl. Unmanned Surface Vehicles - USV)

Na tragu toga, opći termin UMS definira se konceptualno kao "elektro-mehanički sustav, bez ljudskog operatera ukrcanog na istom, koji je u stanju koristiti svoju snagu za obavljanje osmišljenih misija i mogu biti mobilni ili stacionarni". ${ }^{37}$

Ovako postavljena definicija upućuje na to da je izraz unmanned, odnosno bespilotan, odrednica onih objekata koji su potpuno samostalni ili u najmanju ruku bez ikakve mogućnosti da se na njega ukrca posada, što bi, s druge strane, dovodilo do zaključka da je izraz autonomous, odnosno autonoman, odrednica onih objekata koji takvu mogućnost ipak imaju. Drugim riječima, da nisu posve samostalni. ${ }^{38}$ Međutim, bez ulaženja u daljnju diskusiju po ovom pitanju, izgleda da je ta klasifikacijska rasprava donekle bespredmetna za potrebe uređenja pravnog prepoznavanja nove vrste objekta (više infra).

Nadalje, s obzirom na prethodno izloženu podjelu koja razlikuje dvije vrste "vozila", valja odmah otkloniti potencijalne dileme te istaknuti kako se često na navedene sustave zna referirati i izrazom Unmanned Maritime Vehicles (UMV), odnosno u slobodnom prijevodu, "bespilotna pomorska vozila". Kao i ranije, ni ovdje se neće ulaziti u posebnu opservaciju pojma "vehicle"39 - osobito onu poredbenopravnu - jer bi se time prešla granica ovoga rada. Stoga ostajemo pri daljnjem konceptualnom izlaganju tehnologije autonomnih pomorskih sustava $\mathrm{u}$ njezinim osnovnim crtama.

Ocijeni li se da predmetni objekti zapadaju u opseg primjene pravila pomorskog prava, a osobito budu li se ta pravila na takve objekte izrijekom aplicirala nekim njihovim de lege ferenda - bilo kao lex specialis ili kao lex specialissima - to čini svaku daljnju diskusiju o njihovoj kriterijskoj podijeli i razlikovanju bespredmetnom. Možda jedini razlog zbog kojeg se takva diskusija vodi jest upravo zbog rješavanja pitanja klasifikacije, odnosno sistematizacije takvih objekata unutar pomorskog zakonodavstva, a otud i načina na koji će se ta pravila na takve objekte reflektirati.

Kako god, ono što je svojstveno svim tim objektima zajedno jest njihova povezanost s morem i poslovima vezanima uz more, mogućnost samostalnog djelovanja (i to najčešće u rasponu), ${ }^{40}$ mogućnost upravljanja na daljinu, uključujući i mogućnost njihova praćenja.

Radi se, naime, o širokoj paleti različitih sustava, uređaja, komponenti, modaliteta rada, odnosno, jednom riječju, mogućnosti, a otud i o različitim vrstama i tipovima

37 Örnfelt M., SARUMS, Safety and regulations for unmanned maritime systems, Prepared for UMS workshop, Porto, Portugal, [PPT], 2014., https://www.google.hr/url?sa=t\&rct =j\&q=\&esrc=s\&source= web\&cd=4\&cad=rja\&uact $=8 \&$ ved=0ahUKEwjT76Tjvo_OAhXK2BoKHVgKDoQQFgg6MAM\&url= http\%3A\%2F\%2Fums2014.inescporto.pt\%2Ffinal-program\%2Fsafety-and-regulations-for-unmannedmaritime systems.pptx\&usg=AFQjCNFKVwKghZcKSYqq9cmFaFlt3xbrTw, (20. VII. 2016.), p. 5.

38 Više o stupnju samostalnosti infra, 2. 1.2.

39 Vidi više: Pajković, M., Da li brod dron ulazi u pojam broda prema hrvatskom pomorskom pravu?, diplomski rad, Pravni fakultet Sveučilšta u Rijeci, Rijeka, 2017., str. 7-8.

40 Više infra, 2. 1.2. 
objekata od kojih su svi, u tehnološkom smislu, vrlo napredni. ${ }^{41}$ Iz tog razloga, izgleda da bi možda faktični izraz "napredni objekti" kao adekvatan referentan termin bio prikladniji za označiti sve moguće pojavne oblike, a u nomotehničkom smislu možda čak i kao "napredni pomorski objekti" (više infra).

\subsubsection{Autonomni brod}

S obzirom na ranije izloženo, autonomni brod potpao bi pod kategoriju (b) "bespilotna površinska vozila (engl. Unmanned Surface Vehicles - USV)" općeg pojma $U M S$, odnosno "naprednih pomorskih objekata" kako smo ih prethodno označili.

Navedena potkategorija USV definira se konceptualno kao "besposadno, samohodno, samonapajajuće pomorsko vozilo koje je sposobno za rad autonomno ili pod kontrolom i zapovjedi na daljinu, bez upotrebe fizičke veze. Ono radi sa stalnim ili približno stalnim dodirom s vodenom površinom $\mathrm{i}$, kada je u stanju mirovanja, istiskuje vodu te je u plutajućem stanju". ${ }^{42}$

S obzirom na dosad navedeno, i ovdje je moguće daljnje razlučivanje USV-a na daljinski upravljive, autonomne i sl., međutim, kako se ranije istaknulo da ovaj vid diskusije nadilazi okvire ovoga rada, o njemu se neće dalje detaljno raspravljati. Osim toga (a kako je ranije istaknuto), pitanje daljinske upravljivosti, odnosno stupnja autonomije ili samostalnosti u djelovanju - izgleda - bespredmetno je jer su ta vrsna obilježja općenito svojstvena "naprednim pomorskim objektima" u cjelini.

Tako primjerice, i Van Hooydonk navodi moguće razlikovanje, u okviru UMS-a, između daljinski upravljanih vozila (Remotely Operated Vehicles - ROVs) i autonomnih vozila (Autonomous Vehicles $-A V s$ ). ${ }^{43}$ No, i ovakvo razlikovanje nadalje izgleda nepotrebno jer se ovakvi modaliteti najčešće manifestiraju i manifestirat će se "u rasponu", i to uključivanjem svih mogućih modaliteta rada zajedno (Više o tome infra, 2. 1. 2.). Stoga ni ne čudi kako je Međunarodna pomorska organizacija (International Maritime Organization, dalje: IMO) svoje stupnjeve autonomnog djelovanja broda izložila nehijerarhijski, pritom istovremeno ne isključujući mogućnost da brod djeluje na jednom ili više stupnjeva autonomije tijekom jednog putovanja. ${ }^{44}$ Ovo je razumljivo, ne samo sa stajališta ranije izložene bespredmetnosti strogog diferenciranja odgovarajućih kategorija, već ponajviše zbog pitanja sigurnosti plovidbe. ${ }^{45} \mathrm{Za}$ kraj, IMO je novu vrstu (naprednog) broda označio kao "pomorski autonomni površinski brod" (engl. Maritime Autonomous

41 Vidi isto: Radionov Radenković, N.; Mandžuka, S., "Autonomne podvodne ronilice: novi pojam hrvatskog pomorskog prava", Poredbeno pomorsko pravo, Vol. 46, No. 161, 2007., str. 43-51.

42 Örnfelt, M., SARUMS, op. cit., u bilj. 35, p. 5.

43 Van Hooydonk, E., op. cit., u bilj. 17 in fine, p. 404.

44 IMO, IMO takes first steps to address autonomous ships, http://www.imo.org/en/mediacentre/ pressbriefings/pages/08-msc-99-mass-scoping.aspx (2. VIII. 2019.).

45 Više infra, 2. 1.2. 
Surface Ship - dalje: MASS) i vrlo koncizno ga definirao kao: "brod koji, u različitoj mjeri, može djelovati neovisno o ljudskoj interakciji". ${ }^{46}$

Pritom je zanimljivo primijetiti kako se IMO u svojoj definiciji koncentrira isključivo na brod, sasvim razvidno isključujući ostale moguće objekte. Dakle, IMO uopće nije ni adresirao druge mogućnosti, odnosno širu problematiku UMS-a, odnosno tzv. "naprednih pomorskih objekta". S druge strane, sagleda li se izričaj koji se koristi za referiranje na novu vrstu naprednog broda, dakle "(...) Surface Ship", onda se daje naslutiti kao da je ostavljena mogućnost da se u perspektivi prepozna kategorija "Maritime Autonomous Underwater Ship", kao nekakva njegova podvodna varijanta. Ovo je pomalo nerazumljivo, osim dakako ako se ne bi pod time aludiralo na podmornice i/ili ronilice te mogućnost analogne primjene pravila i na njih.

Konačno, ono što je također zanimljivo zamijetiti jest to što je IMO u stilizaciji svoje definicije primijenio metodu definiranja relevantnih brodova po kriteriju njihove osnovne značajke, naglašavajući dakle njihovu jedinstvenu osobinu autonomnog djelovanja.

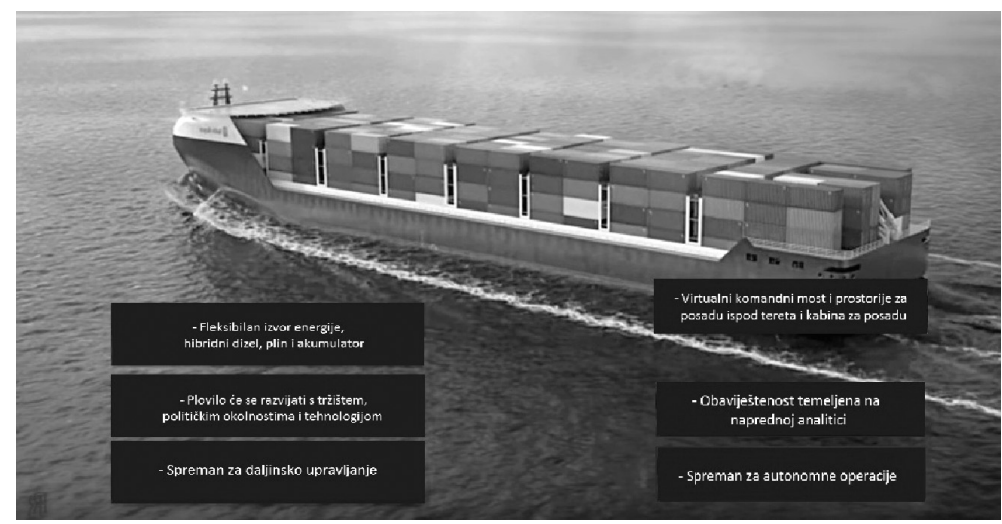

Slika 1: Rolls-Royceov prikaz dizajna autonomnog broda koji bi bio u suglasju s važećim propisima (siječanj 2017.)

\subsubsection{Stupnjevi autonomije}

Premda se faktično može razlikovati nekoliko koncepcija tehnologije autonomnog brodarstva pa otud i različiti nazivi poput besposadnih brodova, daljinski upravljivih, automatiziranih, autonomnih i sl., u suštini riječ je o istoj tehnologiji u različitim fazama razvoja i načinima rada pri čemu se te faze i načini rada najčešće preklapaju ili kombiniraju.

Pa iako je konačan cilj "potpuno autonoman besposadan prekooceanski brod" (engl. autonomous unmanned ocean-going ship), odnosno "robot plovilo" ili "robot

46 U izvornom engleskom: "a ship which, to a varying degree, can operate independently of human interaction". 
brod" (engl. robo-vessel), nije izgledno da će takav brod ikada biti lišen nadzora i mogućeg preuzimanja kontrole s kopna. Na tom tragu, valja napomenuti da je čak i u Dodatku prijedlogu Rezolucije o pravilima građanskog prava o robotici (dalje: EU Rezolucija), koju je 16. veljače 2017. prihvatio Europski parlament, uključena preporuka integriranja opt-out mehanizama, odnosno prekidača za prestanak rada (engl. kill switches) kada su robotski sustavi u pitanju. ${ }^{47}$

Stoga je varijanta "autonomnog" broda koji je opremljen uređajima i sustavom koji mu omogućava da djeluje autonomno, uz dodatnu mogućnost stupnjevanja razine samostalnog djelovanja, pri čemu posreduje odobalni kontrolni centar ${ }^{48}$ koji provodi nadzor i ima mogućnost upravljanja brodom, ona varijanta koja je najizglednija, ali i po oživotvorenju vremenski najbliža.

S druge strane, aspiracija za potpuno autonomnim brodom ostaje samo kao opcija kojoj se može pribjeći kao jednom od stupnjeva rada brodskog sustava (dakle onom najvišem), ili alternativno kao futurističkoj ideji koja možda postane moguća onda kada čovječanstvo u najmanju ruku postigne takav tehnološki stupanj UI koji se može opisati kao umjetna opća inteligencija (engl. artificial general intelligence - AGI; UOI), odnosno jaki UI (engl. strong AI). ${ }^{49}$ Iako su potpuno autonomni (besposadni) brodovi stvar nešto dalje budućnosti i kao takvi posebne tehničke naravi, po autorovu mišljenju, za njih bi trebala (i bila moguća) primjena mutatis mutandis jednakih pravnih rješenja kao i za brodove koji se nalaze na nižem stupnju autonomnosti, tj. nad kojima postoji mogućnost nadzora i neposrednog preuzimanja kontrole iz obalnog centra, i to iz jednostavnog razloga jer njihov generalni način djelovanja predstavlja ujedno najviši mogući stupanj ovih vremenski bližih autonomnih brodova. Dakako, pritom mogućnost prilagodbe propisa njihovim specifičnim obilježjima nije isključena. Ovo ide ujedno u prilog već ranije istaknutom, a to je da su diferenciranje objekata s obzirom na modalitete rada i/ili stupnjeve autonomije, bespredmetni kako zbog općenite odlike "naprednih pomorskih objekata" da djeluju na različite načine koji se mogu kombinirati (i to u rasponu), tako i sa stajališta sigurnosti plovidbe.

47 Prilog Rezoluciji Europskog parlamenta od 16. veljače 2017. s preporukama Komisiji o pravilima građanskog prava o robotici (2015/2103(INL)), "Dozvola za projektante", alineja 4.

48 Obalni kontrolni centar (shore control centar - SCC) predstavlja potpuno novi entitet u pomorskoj domeni. Kao novi oblik upravljanja, u njemu će se nalaziti ključne osobe koje će zamijeniti članove posade na današnjim konvencionalnim brodovima. Organizacijsku strukturu SCC-a čini pet situacijskih prostorija, 45 radnih stanica te dva odjela. Jedan odjel za nadziranje brodova dronova koji će djelovati 24 sata 7 dana u tjednu te drugi odjel za planiranje i potporne aktivnosti praćen radom u jednoj smjeni. Također, obilježje SCC-a je njegova jedinstvena organizacijska struktura koja se sastoji od tzv. SCC kapetana (captain), nadzornika (supervisor), upravitelja stroja (ship engineer) te konačno operatera (operators). Vidi: Corić, D.; Pajković, M., op. cit., u bilj. 1, str. 109., bilj. 8.; Više infra, 4.

49 Oblik umjetne inteligencije koji karakterizira takav tip tehnološkog dostignuća pri kojem stroj konačno može "razmišljati" jednako dobro kao i čovjek te kada stroj počne izvršavati poslove koje danas ljudi obavljaju s lakoćom, tada možemo reći da se dostigla umjetna opća inteligencija. Neki procjenjuju da će se takav tip umjetne inteligencije dostići za nekih 30 godina, neki su mišljenja da će to biti puno dulje vrijeme, dok drugi poput Noama Chomskyja, smatraju da je tehnologijski singularitet tek znanstvena fantastika. Callaghan, V.; Miller, J.; Yampolskiy, R.; Armstrong, S. (Ed.), The Technological Singularity: Managing the Journey, 1st edition, 2017., pp. 209-210. 
Stoga, ako nije riječ o nomotehničkim rješenjima koja se bave pitanjima odgovornosti i naknade štete, rasprava o strogom sistemskom diferenciranju različitih vrsta istovrsnih objekata s obzirom na način njihova rada, izgleda, nepotrebna je, ako već nije preuranjena. To tim više, ako se u obzir uzmu nomotehničke mogućnosti da se stilski u definiciju ili drugu odredbu ugrade izričaji fakultativnog ili alternativnog karaktera koji omogućavaju postojanje različitih oblika istovrsnog objekta unutar iste odredbe (vidi više infra 3.).

\section{AUTONOMNI PLOVNI OBJEKT U HRVATSKOJ POMORSKO-PRAVNOJ NOMENKLATURI I NJEZINI UČINCI}

\subsection{Autonoman plovni objekt kao pojam}

Prije donošenja Zakona o izmjenama i dopunama Pomorskog zakonika, Narodne Novine, br. 17/2019 (dalje: ZIDPZ) hrvatsko pomorsko pravo nije izrijekom poznavalo autonomnome plovne objekte poput autonomnih ronilica, autonomnih brodova i drugih sličnih objekata, već se njihova prepoznatljivost unutar zakonskih normi izvlačila posredno tumačenjem. Ovakva situacija dovodila je do određenih nedorečenosti po pitanju upisa odgovarajućeg plovila, zatim odgovornosti, osobito prava njezina ograničavanja, nadalje pitanja prisutnosti i popunjenosti posadom te načina pohranjivanja brodske dokumentacije itd.

Dok su, međutim, pojedina pitanja neposredno ili posredno odgovarajućim tumačenjima bila rješiva, druga su bila diskutabilna u provedbi i primjeni. Ista situacija bila je, i dalje jest, na međunarodnom planu $^{50} \mathrm{~s}$ obzirom na to da se sličan zahvat u međunarodnom pomorskom pravu nije još zbio, izuzev dakako definicije IMO koja se pritom odnosi samo na autonomne brodove, a ne i UMS, odnosno napredne pomorske objekte. Međutim, ni ta definicija nije obvezujuće niti normativne naravi, već samo kao vid procjene i usmjerenja.

U hrvatsko pomorsko pravo, s druge strane, uveo se termin autonomni plovni objekt. Promatrajući definiciju, na prvi pogled djeluje da je dosta opširno postavljena. Ovo dovodi do zaključka da hrvatsko pomorsko pravo uslijed najrecentnijih izmjena prepoznaje pojedine objekte unutar prethodno razmotrenog UMS-a. Naime, prema čl. 5, st. 1., t. 1. konsolidiranog teksta Pomorskog zakonika ${ }^{51}$ (dalje: PZ) autonomni plovni objekt je:

"plovni objekt koji ovisno o stupnju automatizacije $i$ zahtjevima za neposrednim nadzorom stalne službe može ploviti bez ukrcane posade ili sa smanjenim brojem članova posade."

50 Norris, A., Legal Issues Relating to Unmanned Maritime Systems Monograph, published on-line, U.S. Naval War College, International Law Department, 2013., p. 21.

${ }^{51}$ Narodne novine, br. 181/04, 76/07, 146/08, 61/11, 56/13, 26/15, 17/19. 
Stoga izloženu definiciju valja u nastavku interpretativno raščlaniti kako bi se shvatilo koje učinke bi zapravo ona potencijalno izazivala. Pritom valja prvo započeti s jezičnim tumačenjem polazeći ponajprije od vječno diskutabilnog pojma "plovni objekt". ${ }^{52}$

\subsubsection{Jezično tumačenje izraza plovni objekt $i$ ploviti}

Premda do danas bespogovorno postoje višestruke definicije "plovnog objekta" ili plovila, u hrvatskom standardnom i strukovnom jeziku ili preteže definicija po kojoj se plovni objekt kreće "po vodi" kao isključivoj mogućnosti, ili se istovremeno proturječi tom značenju bilo tako da se podmornice i ronilice određuje kao plovne objekte, ili da se zanemaruje sama etimologija i značenje određenih izraza. Primjera radi, definicija koja glasi: "podmornica, plovilo konstruirano za podvodnu plovidbu (...)". ${ }^{53}$ Stoga izgleda da nema jedinstvene definicije.

No unatoč tome, ipak bi se moglo reći da "plovni objekt" ili plovilo zapravo predstavlja svaki objekt ili napravu koritastog oblika, ${ }^{54}$ odnosno objekt koji ima vodonepropusni prostor te označava opći izraz za sve što je kao takvo sposobno plutati, a otud i ploviti. Naime, izraz ploviti, osim kretati se po površini vode u određenom smjeru (dakle u slučaju čamca, broda i sl.), znači i plivati (stsl. pluti, prasl. plyti, rus. plyt', češ. plouti). ${ }^{55}$ Oba izraza na neki su način ekvivalentna, odnosno izomorfna jednako kao što je izraz plutati izomorfan izrazu plivati. ${ }^{56}$ Dakle, svako plovilo, od broda do podmornice, ima svojstvo plovnosti koje mu omogućava da ostaje na površini, odnosno da pliva ili pluta. Povrh tog općeg svojstva, pojedina plovila, odnosno objekti imaju, temeljem svojih tehničkih obilježja, ujedno i sposobnost zaranjati ili roniti te se tako kretati, odnosno ploviti posve uronjeno. ${ }^{57}$ Pored raznih terminoloških određenja, plovni objekt još se definira i kao objekt za plovidbu morem. ${ }^{58}$

52 Vidi više: Harašić, Ž., "Dometi sistematskog tumačenja u pravu", Zbornik radova Pravnog fakulteta u Splitu, vol. 46, br. 2, 2009., str. 333; također vidi: Kačer, H., "(Ne)usklađenosti nekih pojmova iz zakona o autorskom pravu i srodnim pravima, obiteljskog zakona i zakona o obveznim odnosima", Zbornik Hrvatskog društva za autorsko pravo, vol. 7., 2006., str. 54-58; isto: Kačer, H.; Ivančić Kačer, B., "O rješavanju antinomija i pravnih praznina (posebno) na primjeru odnosa zakona o sportu i zakona o obveznim odnosima", Zbornik radova Pravnog fakulteta u Splitu, vol. 54, br. 2, 2017., str. 397-414.

53 Pomorski leksikon, Leksikografski zavod Miroslava Krleže, dostupno na: http://pomorski.lzmk.hr/ clanak.aspx?id=9222 (5. IV. 2020.).

54 Hrvatski leksikon (online platforma), dostupno na: https://www.hrleksikon.info/definicija/plovilo. htm (5. IV. 2020.).

55 Hrvatski jezični portal (online platforma), dostupno na: http://hjp.znanje.hr/index. php?show=search_by_id\&id=eV1uXhg\%3D (5. IV. 2020.).

56 Hrvatski jezični portal (online platforma), dostupno na: http://hjp.znanje.hr/index.php?show= search_by_id\&id=eV1uWRM\%3D (5. IV. 2020.).

${ }_{57}$ Ibid., bilješka 51; također: Hrvatska tehnička enciklopedija, Leksikografski zavod Miroslav Krleža, portal hrvatske tehničke baštine, https://tehnika.lzmk.hr/podmornica/ (5. IV. 2020.); Vidi isto obrazloženje o podmornici kao plovnom objektu na: Hrvatski terminološki portal, Institut za hrvatski jezik i jezikoslovlje, http://nazivlje.hr/clanak/je-li-podmornica-plovni-objekt/20/ (5. IV. 2020.).

58 Struna - hrvatsko strukovno nazivlje, Institut za hrvatski jezik i jezikoslovlje, dostupno na: http:// struna.ihjj.hr/naziv/plovni-objekt/22042/ (5. IV. 2020.). 
S pojmom ploviti stoga je u vezi i pojam plovidbe, čije značenje prema domaćoj pomorskopravnoj teoriji podrazumijeva "kretanje plovnog sredstva vodenim medijem".${ }^{59}$ Dakle, pošto "kretanje vodenim medijem" izrijekom ne podrazumijeva isključivo kretanje po površini vode već, po autorovu dojmu, aludira na kretanje u rasponu cijele njegove mase - dakle, i kroz vodeni medij - može se zaključiti da znači ne samo kretanje po njegovoj površini nego i ispod površine, odnosno kroz vodeni medij.

Slijedom navedenog, razvidno je da pojam plovnog objekta održava uz brodove i neke druge objekte poput podmornice, batiskafa, ronilice.

\subsubsection{Fakultativne i alternativne značajke definicije}

Ako se promotri preostali dio definicije uočit će se da ista sadrži određene dijelove koji upućuju na fakultativnu ili alternativnu mogućnost u funkcioniranju autonomnog plovnog objekta. Prema PZ-u, autonomni plovni objekt je dakle takav objekt koji, ovisno o svojim tehničkim mogućnostima: "(...) može ploviti bez ukrcane posade ili sa smanjenim brojem članova posade". Ovo upućuje na to da predmetni objekt u rasponu različitih mogućnosti i njegovih pojavnih oblika "može", argumentum a contrario, "i ne mora" imati prostorije za posadu jer - može i ne mora - ploviti s posadom koja - može i ne mora - biti standardne brojčane popunjenosti, budući da je u stanju djelovati i sa smanjenim brojem članova posade.

To, dakako ovisi - kako definicija u PZ-u nalaže - "(...) o stupnju automatizacije i zahtjevima za neposrednim nadzorom stalne službe (...)".

Ovakvo određenje jednako tako upućuje na raspon različitih mogućnosti od daljinskog upravljanja via "stalne službe" (ili nekog drugog entiteta) do potpuno samostalnog djelovanja, odnosno autonomnosti. Pritom su argumentum rerum natura ovdje moguće i različite mogućnosti koje nalazimo primjerice u IMO-shemi stupnjeva autonomnog djelovanja ili nekih drugi. ${ }^{60} \mathrm{Na}$ temelju toga, s obzirom na način na koji je definicija autonomnog plovnog objekta konceptualno postavljena, moguće je izvesti i različite druge oblike naprednih objekata koji primjerice imaju visok stupanja autonomnosti uslijed kojeg nije potrebna posada (pa slijedom toga ne disponira prostorijama u kojima bi ona bila smještena) te tako plovi bez ukrcane posade. Slijedom navedenog, ovdje dakle uz, primjerice, autonoman brod, može biti riječ i o nekom drugom objektu poput ronilice.

Konačno, valja još promotriti dio definicije koji se referira na "stupanj automatizacije". Naime, u raspravama i različitim analizama, elaboratima i sl. ponekad se koristi izraz automatizirani brod (engl. automated vessel), međutim,

59 Jakaša, B., Udžbenik plovidbenog prava, Narodne novine, Zagreb, 1979., str. 1.; isto: Skorupan Wolff, V., "Koncept stvarne nadležnosti sudova u plovidbenim sporovima (analiza de lege lata)", Zbornik pravnog fakulteta Sveučilišta u Rijeci, vol. 39, br. 2., Rijeka, 2018., str. 971., bilj. 95.

${ }_{60}$ Vidi infra 4. 1.; također Vojković, G.; Milenković, M., "Novi pravni okvir i klasifikacija autonomnih, daljinski upravljanih i srodnih brodova", Zbornik radova 2. Međunarodne znanstvene konferencije iz pomorskog prava - Suvremeni izazovi pomorske plovidbe (ISCML), Pravni fakultet Sveučilišta u Splitu, Split, 2018., str. 395-399. 
autor smatra da termin automatizirani brod nije adekvatan referentan termin u odnosu na koncept nove brodarske tehnologije s obzirom na to da je već danas znatan dio brodskih komponenti i uređaja automatiziran na brodovima. ${ }^{61}$

Tako današnji automatizirani brod kao struktura ima integrirani brodski sustav koji se sastoji od različitih podsustava kao što su usmjeravanje, stabilizacija, propulzija, hlađenje, utovar itd. ${ }^{62}$ Sigurno djelovanje broda ovisi o kontinuiranom i pouzdanom radu svih tih podsustava, dok uvođenje automatizacije glede njih doprinosi optimizaciji njihovih operativnih parametara. ${ }^{63}$

U odnosu na konvencionalne sustave kontrole, uvođenjem u sustav sve više tzv. tehnologije UI dovodi do postupnog povećanja stupnja automatizacije broda pri čemu bi bilo bolje govoriti o visokoautomatiziranom brodu (highly automated ship). Dakako tu je granica između automatizacije i autonomije sve tanja pa se tek tada na konceptualni brod s apsolutnim stupnjem automatizacije valja referirati kao na autonoman brod (autonomous ship) ${ }^{64}$ Dakako, ovo ne isključuje mogućnost da se nad takvim brodom preuzme kontrola ili pak vrši nadzor njegova djelovanja u cijelosti. Stoga je izričaj koji koristi PZ u svojoj definiciji u potpunosti razumljiv, ali ujedno i neisključiv u smislu vrste naprednih objekata koje potencijalno zahvaća.

\subsection{Učinci pravnog pojma autonomnog plovnog objekta}

Novouvedeni pojam autonomnog plovnog objekta prema zamisli zakonodavca predstavlja novi pojam koji, takoreći, dodatno definira neka obilježja plovnih objekata. Međutim, uvođenjem novog pojma uvela se u određenom opsegu i konfuzija. Stoga valja promotriti koje učinke izaziva novouvedeni pojam, a time koje mogućnosti i nedorečenosti.

Polazeći od relevantne definicije, sasvim je razvidno da će svaki faktični objekt koji se po svojim karakteristikama podudara s definicijom autonomnog plovnog objekta biti pravno tretiran kao takav.

Nadalje, osobitu pažnju treba skrenuti i na korijen definicije koji polazi od "plovnog objekta", a koji upućuje na to da će se sva pravila koja se inače primjenjuju

61 Isto tako u: Ćorić, D.; Pajković, M., op. cit., u bilj. 1, str. 108-109.

62 Smierzchalski, R., Intelligent Marine Control Systems, Enhanced Methods in Computer Security, Biometric and Artificial Intelligence Systems, Springer US, 2005., p. 311.

63 Loc. cit.

${ }^{64}$ Znanost koja u ovom području ima također jedan od velikih utjecaja jest automatika. Znanost je to o općim principima projektiranja, realizacije i primjene automatskog uređaja i sustava koji mogu izvršavati svoje osnovne funkcije bez neposrednog sudjelovanja čovjeka. Na tragu toga automatizacija označava primjenu metoda i sredstva automatike za pretvaranje neautomatskih strojeva, uređaja i proizvodnih procesa u automatske. Područje automatizacije jesu: nadzor, signalizacija, zaštite, blokade, upravljanje, regulacije, vođenje procesa. Unutar ovoga postoji i pojmovno određenje automatskog sustava koji se definira kao pojedina postrojenja, strojevi i uređaji koji sudjeluju u proizvodnom procesu i koji su međusobno tako povezani i tehnički opremljeni da sami izvršavaju postavljeni zadatak bez neposrednog sudjelovanja čovjeka (Tomas, V.; Šegulja, I.; Vlačić, M., Osnove automatizacije, Pomorski fakultet u Rijeci, Sveučilište u Rijeci, Rijeka, 2010., str. 1.). Integriranjem suvremene tehnologije u području UI-a u okvir takvog sustava koji nalazimo na autonomnom brodu dovodi do novog poimanja automatizacije, ali i de facto stvaranja robota svoje vrste. 
na plovne objekte 65 jednako tako primjenjivati i na autonomne plovne objekte. Polazeći od sadržaja PZ-a, predmetna pravila koja vrijede za plovne objekte podrazumijevaju one odredbe koje se referiraju na njih kao takve, a te se odredbe manje-više nalaze razbacane u:

- Dio 2 - Morski i podmorski prostori Republike Hrvatske [Glava II -Unutarnje morske vode, Glava III - Teritorijalno more, Glava IV - Gospodarski pojas, Glava VI - Pravo progona]

- Dio 3 - Sigurnost plovidbe i zaštita od onečišćenja pomorskih objekata [Glava I - Zajedničke odredbe, Glava I.a - Zaštita od onečišćenja s pomorskih objekata, Glava I.b - Istrage pomorskih nesreća, Glava II - Poslovi sigurnosti plovidbe i zaštite mora od onečišćenja, Glava II.a - Poslovi traganja i spašavanja osoba u pogibelji na moru, Glava III - Luke i ostali dijelovi unutarnjih morskih voda, Glava IV - Plovidba i peljarenje, Glava IV.a - Nadzor i upravljanje pomorskim prometom, Glava IX - Inspekcijski nadzor]

- Dio 7 - Ugovori [Glava II - Ugovori o iskorištavaju pomorskih brodova konkretno čl. 637: "Ako tegljač tegli plovni objekt koji nema posadu (...)"]

- Dio 8 - Pomorske nesreće [Glava I - Sudar brodova - točnije čl. 748 koji navodi da se odredbe ove glave Zakonika primjenjuju na svaki plovni objekt bez obzira na njegovu namjenu, te hidroavion na vodi; čl. 823.a pod odjeljkom - Odgovornost za onečišćenje mora pogonskim uljem, koji ističe da "(z)a potrebe ovog odjeljka ove glave Zakonika: 1. (b)rod znači svaki plovni objekt bilo koje vrste (...)"]

- Dio 10 - O mjerodavnom pravu i o nadležnosti sudova Republike Hrvatske [Glava II - O mjerodavnom pravu i o isključivoj nadležnosti sudova Republike Hrvatske za odnose s međunarodnim obilježjem (elementom) - pod uvjetom da se plovni objekt smatra brodom prema hrvatskom pravu ili pravu države čiju državnu pripadnost ima (čl. 967).]

- Dio 11 - Pomorski prekršaji [Glava II - Prekršaji]

- Dio 12 - Ovlaštenja, prijelazne i završne odredbe.

Prema tome, pojavljuje se neizbježna primjena onih pravila koja se primjenjuju na svaki objekt koji se može shvatiti kao "plovni objekt". Ovo podrazumijeva i ona pravila koja odražavaju pravila međunarodnog prava mora, koja se definitivno primjenjuju inače na svaki plovni objekt, odnosno plovilo (engl. vessel). To, dakako, ne znači da će sve potencijalno primjenjive odredbe biti ujedno i prikladne u svakoj situaciji u kojoj se pojave plovni objekti, točnije njihove autonomne inačice, a osobito autonomni brodovi budući da je cjelokupni sustav postojećih pravnih pravila konstruiran s premisom da takvim objektima upravlja ljudska posada koja se nalazi ukrcana na njemu. Izgleda stoga kako će mnoštvo odredbi zasigurno izgubiti svoj izvorni smisao kada su autonomni brodovi u pitanju, jer iste postaju neprovedive, nelogične ili štoviše nelogične uopće provoditi.

65 Prema čl. 5., st. 1., t. 27. PZ-a, plovni objekt jest pomorski objekt namijenjen za plovidbu morem. Plovni objekt može biti brod, ratni brod, podmornica, jahta ili brodica. 
Definicija zakonodavca, može se reći, pomalo je nezgrapno implementirana s obzirom na to da se njome tretira suviše apstraktan pojam, točnije plovni objekt, umjesto da se to učinilo u pogledu konkretnijeg pojma kao što je brod i pritom kreirala nova vrsta - autonomni brod. U prilog tome ide i činjenica da je čak IMO formulirao pojam MASS fokusirajući se isključivo na brod, ali ne ujedno i na sva druga plovila i objekte čije je postojanje, kada je u pitanju PZ, zakonodavac na neki način prepoznao i njihovo postojanje u okviru PZ-a omogućio (više infra, 3. 2. 3.).

$\mathrm{S}$ druge strane, metoda kakvu je primijenio zakonodavac donekle je shvatljiva jer je tehnologiju kakvom disponira autonoman brod moguće implementirati i na ratni brod, podmornicu, jahtu ili brodicu.

\subsubsection{Autonoman brod unutar Pomorskog zakonika?}

Polazeći od postojeće pravne konstelacije, može se zaključiti da su uvođenjem pravnog pojma autonomnog plovnog objekta službeno autonomni brodovi prepoznati od strane hrvatskog pomorskog prava. Dakle, ispunjavaju li ti objekti, a među njima osobito MASS, odnosno autonomni brod, pravne preduvjete za stjecanje statusa broda (navis) onda bi se isti pravno shvaćali kao brod.

Prema tome, prepoznavanje autonomnog broda unutar PZ-a osobito je moguće uzme li se u obzir da je relevantni objekt ponajprije određen kao "plovni objekt". Naime, ako sukladno čl. 5., st. 1., t. 27. "plovni objekt" može biti brod, ratni brod, podmornica, jahta ili brodica, a autonomni plovni objekt sa svojim differentia specifica (iako posebne vrste) jest "plovni objekt", onda posredstvom pravne logike $\mathrm{i}$ interpretacije teksta Zakonika, autonomni plovni objekt može također biti brod, ratni brod, podmornica, jahta ili brodica, zbog toga što je "plovni objekt".

$\mathrm{S}$ tim u vezi, valja nadalje sagledati pravnu definiciju broda prema PZ-u:

"brod, osim ratnog broda, jest plovni objekt namijenjen za plovidbu morem, čija je duljina trupa veća od $15 \mathrm{~m}$, ili je ovlašten prevoziti više od 12 putnika. Brod može biti putnički, teretni, tehnički plovni objekt, ribarski, javni ili znanstvenoistraživački" (čl. 5., st. 1., t. 2.).

Slijedom izloženog, može se zaključiti da ukoliko autonomni plovni objekt udovolji kriterijima pravnog određenja broda (navis), utoliko on kao takav također čini autonoman brod (navis autonoma) ili čak besposadni brod (navis sine chors).

Otud nadalje, moguće su različite potkategorije autonomnih brodova s obzirom na njihovu namjenu, uključujući njihove različite koncepte u kojima se ova nova brodarska tehnologija pojavljuje. Ovo je, izgleda, posebno moguće budući da pravna definicija broda, enumerira različite tipove brodova, kao što su ranije spomenuti, putnički, teretni, tehnički plovni objekt, ${ }^{66}$ ribarski, javni ili znanstvenoistraživački

66 Vidi više: Tuhtan Grgić, I., O nekim aspektima $i$ implikacijama pravnog statusa odobalnih objekata za istraživanje i eksploataciju ugljikovodika u Republici Hrvatskoj, Pomorski zbornik, Vol. 51, No. 1, 2016. in extenso. 
pa tako učinci novouvedene definicije čak otvaraju mogućnost da različite podvrste brodova budu ujedno autonomni.

Premda mogućnost identificiranja autonomnog broda, kao i pitanja primjene odgovarajućih pravila izgledaju prima facie jasna i jednostavna, naravno, to je daleko od istine s obzirom na to da učinci i implikacije, osobito one imovinskopravne naravi, i dalje ostaju.

\subsubsection{Redefinicija autonomnog broda?}

Konačno, u svjetlu Hooydonkova tzv. "prava autonomnog brodarstva" bilo bi preporučljivo promotriti možda i neka drugačija nomotehnička rješenja u odnosu na postojeća, posebno ako se uzmu u obzir problematika i nedorečenosti oko uvođenja autonomnog plovnog objekta, što zakonodavac možda želi izbjeći.

U tom smislu, prikladnije rješenje bilo bi možda autonomne brodove izdvojiti kao posebnu kategoriju jednako kao što se učinilo u slučaju nuklearnog broda, kako je definiran čl. 5, st. 1., t. 24. PZ-a. ${ }^{67}$ Pritom bi bilo prikladno koristi i jednaku metodu definiranja ove napredne vrste broda, dakle, s obzirom na njegova specifična obilježja. Slijedom navedenog, autonomni brod mogao bi se definirati kao:

Brod opremljen tehnologijom koja mu može omogućiti navigaciju bez. aktivne fizičke kontrole ili nadzora od strane čovjeka.

Normativno određenje takvog plovnog objekta poslužilo bi kao baza za kreiranje propisa i reguliranje pitanja plovidbene sposobnosti (engl. seaworthiness), odnosno usklađenosti sa specifičnim tehničkim pravilima, a posebice za reguliranje pitanja odgovornosti. U tom smislu, bilo bi možda preporučljivo isto tako, a po uzoru na američki model definicije autonomnog motornog vozila (engl. autonomous vehicle), i po principu enumeracije nabrojati što ne predstavlja autonomni brod, tj. za primjenu koje tehnologije se ne smatra da konstituira autonoman brod. ${ }^{68}$

\subsubsection{Drugi napredni objekti}

Suprotno popularnom ili, bolje rečeno, dosadašnjem shvaćanju plovnih objekata kao numerus clausus izgleda da je uvođenje novog pojma na neki način omogućilo i postojanje drugih vrsta naprednih objekata. Ovo je moguće iz više razloga, a prvi je među njima način definiranja autonomnog plovnog objekta tako da zahvaća širi pojam UMS-a, osobito ako se uzme u obzir ekstenzivnost koncipiranog termina, zatim referiranje na apstraktniji pojam "plovnog objekta", te naposljetku postavljanje definicije na takav način da izgleda kao da održava zasebnu kategoriju "plovnog

117.

${ }^{67}$ Pajković, M., op. cit., u bilj. 37, str. 12-13; Isto tako Ćorić, D.; Pajković, M., op. cit., u bilj. 1, str.

68 California Vehicle Code, As Recodified and Reenacted by the 1959 Regular Session of the Legislature and as Amended to the Close of the 2014 Regular Session (CVC), California Legislative Information, Division $16.6 \S 38750$ (a) (1) i (a) (2) (B). 
objekta". ${ }^{69}$ Ovo je još očitije kada se uzme u obzir definicija plovnog objekta koja prema PZ-u glasi:

"(plovni objekt) jest pomorski objekt namijenjen za plovidbu morem. Plovni objekt može biti brod, ratni brod, podmornica, jahta ili brodica."70

Dakle, uslijed uvođenja novog pojma autonomnog plovnog objekta, izvorna definicija plovnog objekta dobiva sasvim novu dimenziju jer i dalje zadržava izričaj "može biti", što - argumentum a contrario - znači da plovni objekt i ne mora nužno biti samo ove vrste koje su u definiciji izložene, već i neka druga vrsta plovila.

Ovo, dakako, nije predstavljalo problem prije uvođenja definicije s obzirom na to da nisu postojale druge vrste plovnih objekata, a sve drugo što se nije uklapalo u postojeće definicije smatralo se pomorskim objektom koji nije zahvaćen pomorskim propisima u mjeri u kojoj je plovni objekt, a kako se ranije izložilo (vidi supra, 3. 2.). Dakle, $\mathrm{u}$ izbjegavanju ove potencijale lacuna legis zakonodavca trebao je $\mathrm{u}$ noveli PZ-a glede plovnog objekta postupiti jednako kao i kod brodice ${ }^{71} \mathrm{kod}$ koje je dodatno specificirao definiciju takvim obilježjima koja sada posve isključuju mogućnost podvođenja pod istu npr. ronilice. $\mathrm{Na}$ jednak način trebalo se pristupiti izmjeni, odnosno korekciji definicije plovnog objekta tako da ona sada glasi: "(...) Plovni objekt (jest/su/jesu) brod, ratni brod, podmornica, jahta ili brodica". Time bi se zadržalo stanje kao prije novele, ali ujedno postiglo željene učinke novog pojma kao termina koji samo odražava dodatna obilježja postojećih plovnih objekata, a ne uvodi potencijalno novi.

U prilog tezi kako definicija "plovnog objekta" po svojoj prirodi sada odražava otvoren skup, ide ne samo postojanje pravne kategorije "autonomnog plovnog objekta" kao naizgled samostalne pravne kategorije, već i dalje prisutni apsurd na koji je ukazala Radionov, a to je negativno pravno normiranje ronilica unutar - sada - novog Pravilnika o brodicama, čamcima i jahtama, ${ }^{72}$ uz istovremeno nedefiniranje ronilica unutar postojećih normi hrvatskog pomorskog prava. ${ }^{73}$ Nadalje, dok su

69 Dakako, ovo ne mora biti definitivno jer moguće su i drugačije interpretacije. Ponajprije u pogledu autonomnog plovnog objekta koji ne mora nužno predstavljati zasebnu kategoriju, već potkategoriju "plovnog objekta". Pritom problem može izazvati takvo restriktivno tumačenje koje bi autonomni plovni objekt kao potkategoriju ili pak varijaciju, a ne zasebnu kategoriju, ograničavalo isključivo na taksativno navedene plovne objekte sadržane u definiciji. S druge strane, ako bi osnovni pojam plovnog objekta ipak označavao numerus clausus, tada se vjerojatno određene pravne kvalifikacije ne bi ni mogle izvesti ovisno o tome primjenjuje li se restriktivna ili ekstenzivna interpretacija. Dakle, ovisno je li riječ o jednom pristupu u tumačenju ili nekom drugom, svaki može polučiti različite situacije, stoga se takvo stanje po pitanju novouvedene definicije ocjenjuje dosta nedorečenim pa bi bilo preporučljivo tu moguću dilemu u budućnosti rasvijetliti. Cf. Ćorić, D.; Pajković, M., op. cit., u bilj. 1, str. 115-117; također, Radionov Radenković, N.; Mandžuka, S., op. cit., u bilj. 39, str. 51-52.

70 PZ, čl. 5., st. 1. t. 27.

71 Sukladno čl. 5., st. 1., t. 7. PZ-a, brodica jest plovni objekt namijenjen za plovidbu morem koji je ovlašten prevoziti najviše 12 putnika, čija je duljina trupa veća od 2,5 metra, a manja ili jednaka 15 metara, ili ukupne snage porivnih uređaja veća od $5 \mathrm{~kW}$. Vidi više o kvalificiranju ronilice kao brodice: Radionov Radenković, N.; Mandžuka, S., op. cit., u bilj. 39 in extenso.

72 Pravilnik o brodicama, čamcima i jahtama, Narodne novine, br. 13/2020, čl. 9.

73 Radionov Radenković, N.; Mandžuka, S., op. cit., u bilj. 39, str. 55. 
podmornice na odgovarajući način zbrinute podvođenjem pod pojam ratnog broda, ili kada su u pitanju komercijalne podmornice, eventualnim podvođenjem analogijom pod pojam broda ${ }^{74}$ ronilice pak ostaju jedan vrlo nedorečen pojam, a s prisutnošću autonomnog plovnog objekta, izgleda, izraženije su više nego ikad.

Protuargument ovoj hipotezi i ovakvom tumačenju bio bi, da aktualizacija propisa nije moguća u smislu u kojem je izloženo iz razloga što je plovni objekt određen kao pomorski objekt koji kao takav nije u stanovitom opsegu zahvaćen pomorskim propisima. Međutim, to bi možda i vrijedilo kada plovni objekt ne bi bio definiran na način koji trenutno jest i kada ne bi postojao autonomni plovni objekt koji se pojavljuje kao alternativa koja pak ovakvo promišljanje u jeku novih tehnoloških mogućnosti i proizvoda ${ }^{75}$ uopće omogućuje.

Stoga se uvođenjem novog pojma uvela u određenom opsegu i konfuzija jer PZ nigdje ne navodi niti ne isključuje mogućnost da nije riječ i o posve novoj vrsti objekta koji se pojavljuje kao dodatak postojećim vrstama plovnih objekata.

Konačno, polazeći od tehničkih specifikacija nekih drugih naprednih objekata, moglo bi se reći da bi dubinski tegljeni sustavi također bili djelomično prepoznati, dok pridnena vozila ipak ostaju izvan postojećeg pravnog okvira hrvatskog pomorskog prava, budući da u smislu jezičnog tumačenja zapravo ne plove, već se kreću po morskom dnu na saonicama ili gusjenicama. ${ }^{76}$

Slijedom navedenog, moglo bi se također reći da je zakonodavac zapravo primijenio ispravnu metodu definiranja, ali ju je primijenio na krivi objekt. Dakle, umjesto da se formulirao pojam autonomnog plovnog objekta, zakonodavac je zapravo trebao formulirati pojam autonomnog pomorskog objekta. Takvim određenjem "autonomni" bi bili samo oni koji po naravi stvari i funkcionalno kao takvi mogu biti, a to su ponajprije i isključivo plovni objekti za koje (kao i za sve njegove podvrste) vrijede sva pravila kao i do sada bez stvaranja dodatne konfuzije i nedorečenosti. Povrh toga, određivanje relevantnog pojma kao ponajprije pomorskog objekta, a ne plovnog kao što se to čini sada, ne bi imalo za rezultat primjenu tolikog opsega pravila kao što je to slučaj kod plovnog objekta.

\section{3. "Autonomni plovni objekt" i klasifikacija de lege ferenda s obzirom na raznolikost vrsta naprednih pomorskih objekata}

$\mathrm{Na}$ tragu autonomnih brodova, treba reći kako normativno prepoznavanje i sistematizacija drugih vrsta naprednih pomorskih objekata ne bi bila na odmet, osobito uzme li se u obzir proliferacija različitih vrsta tehnologija. Ovo posebice vrijedi ako se u obzir uzme i činjenica da nova tehnologija UI ima potencijal pronaći

\footnotetext{
74 Ibid., str. 53.

75 Primjeri podvodnih vozila: DeepFlight Super Falcon, The Triton 3300/3, Innespace Seabreacher, C Quester 3 Submersible i sl.

76 Vidi više o drugim vrstama naprednih pomorskih objekata: Radionov Radenković, N.; Mandžuka, S., op. cit., u bilj. 39, str. 53.
} 
svoju primjenu i u drugim potkategorijama plovnog objekta, poput jahte, ${ }^{77}$ brodice te osobito ratnog broda i podmornica čije je živuće primjere moguće pronaći već danas bilo u formi pravno diskutabilnih autonomnih ronilica ili moćnih lovaca na podmornice - Sea Hunter ratnog broda.

Naime, kako se dosad moglo zaključiti, pravnim pojmom "autonomnog plovnog objekta", ali i "pomorskog objekta" ne uspijevaju se obuhvatiti sve vrste naprednih objekata, odnosno UMS, ostavljajući stoga određene objekte, npr. pridnena vozila, izvan dometa definicije. Takva pravna konstelacija pozicionira određene napredne objekte, dijelom u pomorsku, a dijelom u civilnu (građansku) domenu prava. Modeliranje takvog pravnog pojma koji bi obuhvatio općenito napredne objekte $u$ svojoj cijelosti bilo bi stoga prihvatljivo.

Kao moguće rješenje, bilo bi možda prikladno preformulirati pravnu kategoriju "pomorskog objekta" na način da uključi četvrtu kategoriju kao na primjer "napredni pomorski objekti" koji su kao takvi "sposobni samostalno ili putem ljudske interakcije kretati se kroz stupac morske vode koji se proteže od njegove površine do morskog dna" (autorova sastavnica). Tako bi definicija "pomorskog objekta" prema čl. 5., st. 1., t. 31. de lege ferenda pored (a) plovnog objekta; (b) plutajućeg objekta i (c) nepomičnog odobalnog objekta; sadržavala i četvrtu kategoriju: (d) napredni pomorski objekt.

Na takvoj, postavljeno ugrubo, ideji, daljnja nomotehnička konstrukcija i dalje zadržava pojam autonomnog plovnog objekta, ali uz revidiranje postojeće definicije, tako da je on sad određen kao: "napredni pomorski objekt koji ovisno o stupnju automatizacije $i$ zahtjevima za neposrednim nadzorom stalne službe može ploviti bez ukrcane posade ili sa smanjenim brojem članova posade", te ga kao takvog pozicionira unutar nove, četvrte kategorije pomorskih objekata. Konačno, uvođenjem "naprednog pomorskog objekta", termin bi se mogao definirati kao:

"pomorski objekt koji, ovisno o modalitetu rada, može funkcionirati $i$

kretati se samostalno i neovisno ili putem ljudske interakcije. Napredni

pomorski objekt može biti pridneno vozilo, dubinski tegljeni sustav, ronilica ili autonomni plovni objekt. ${ }^{178}$

S ovakvom novelom oni faktično zvani "napredni objekti", odnosno UMS bili bi u svome totalitetu pravno prepoznati te bi se otud s lakoćom mogli nadalje urediti. Povrh toga, autonomni plovni objekt kakav de lege lata poznajemo, sada bi bio pozicioniran unutar posebnog sustava pravila unutar kategorije "naprednih pomorskih objekata" odvojene od ostalih kategorija "pomorskih objekata", dok bi istovremeno služio svrsi aktualizacije propisa vezanih za autonoman način djelovanja

77 Vidi primjer patenta registarski broj: P20070380, Bežični daljinski upravljač za jahte (engl. Wireless remote controller for yachts), izumitelja i nositelja patenta: Giuseppe Brianza, dostupno: https:// it-app.dziv.hr/Pretrage/hr/p/Detaljno.aspx/20070380 (03.04.2020.), isto: https://it-app.dziv.hr/Slike/Pat_ dok/T_opis/20070380_T3.pdf (3. IV. 2020.).

${ }_{78}$ Poanta u ovom grubom konceptu taksativno navedenih objekata je u "autonomnom plovnom objektu" i njegovu repozicioniranju unutar novog (šireg) pravnog pojma; ostali navedeni objekti izloženi su samo kao primjer. Dakle, moguće su i drugačije formulacije potkategorija. 
kada su u pitanju ostali pomorski objekti koji disponiraju takvom tehnologijom, bilo da je riječ o plovnim objektima općenito ili samo brodu.

Naravno, definicija plovnih objekata bila bi unutar ovakve sistematizacije revidirana na način kako je opisano u 3. 2. 3., dok bi konfuzija i nedorečenosti s ronilicama bila u potpunosti izbjegnuta na način da bi se izrijekom prepoznale kao ronilice (ili sl. $)^{79}$ unutar kategorije naprednih pomorskih objekata, ili bi se posve izbjegla ograničavanjem njezina postojanja tek unutar granica naprednog (pomorskog) objekta i manjkom primjenjivih pravila. Povrh toga, a kako se može vidjeti iz Slike 2., novom kategorijom pomorskog objekta obuhvatili bi se, ili barem dala mogućnost da se obuhvate i lakše urede drugi mogući objekti. Dakle, putem ove nove nomotehničke konstrukcije, uspostavila bi se sveobuhvatna opća pravna veza između različitih postojećih i novih izraza, zadržavajući ujedno potreban opseg razgraničenja između različitih pojmova, uz, dakako, očuvanje tradicionalne i izvorne hrvatske pomorsko-pravne nomenklature i klasifikacije uz istovremeno lakše isključivanje odgovarajućih objekta iz primjene tamo gdje je njihova prisutnost nelogična ili nepotrebna.

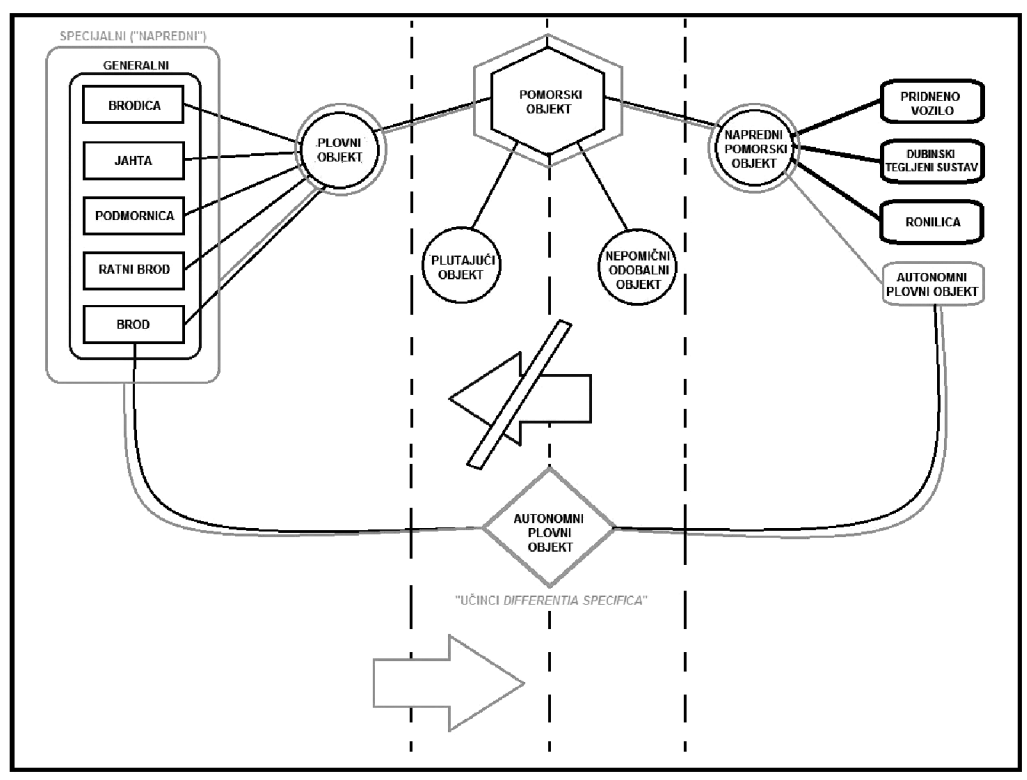

Slika 2: Shema normativne sistematizacije izložene u tekstu

\subsubsection{Rezultat nove normativne sistematizacije i misaoni eksperiment}

Kako bi se dokučilo na koji način bi ovako sistemski predstavljena formulacija različitih definicija funkcionirala, izložit će se sljedeći misaoni eksperiment. plovilo. 
Kako je ranije zaključeno u potpoglavlju 3. 2. 1., naime, ako je "autonomni plovni objekt" po svojoj definiciji "plovni objekt koji ovisno o stupnju automatizacije $i$ zahtjevima za neposrednim nadzorom stalne službe može ploviti bez ukrcane posade ili sa smanjenim brojem članova posade", a prema PZ-u "plovni objekt" jest "pomorski objekt namijenjen za plovidbu morem", koji "može biti brod, ratni brod, podmornica, jahta ili brodica", onda to dovodi do zaključka da "autonomni plovni objekt" sa svojim differentia specifica koji je po definiciji isto "plovni objekt" (iako posebne vrste), može jednako tako biti "brod, ratni brod, podmornica, jahta ili brodica", konstituirajući tako njihovu autonomnu inačicu, točnije autonomni brod.

Unutar novo koncipirane sistematizacije učinci postojanja autonomnog broda, ali uz istovremeno isključivanje jednako vrijedne primjene pravila u odnosu na objekte za koje se to nije namjeravalo, postigli bi se na istovjetan način. Naime, ako je (A): "autonomni plovni objekt", odnosno "napredni pomorski objekt" koji su s obzirom na svoju prirodu, odnosno po svojstvima; (B): "autonomni" u djelovanju (per definitionem), a koji su u ovoj alternativnoj normativnoj konstrukciji određeni sada kao; (C): "pomorski objekti"; pri čemu su (D): plutajući objekt, nepomični odobalni objekt, ali, još bitnije, plovni objekt (a time i njegove podvrste "brod, ratni brod, podmornica, jahta ili brodica") također pravno (C): pomorski objekt, onda je; (D): plovni objekt, točnije brod; zapravo jednako (B): "autonoman" ispunjava li kriterije definicije (A): "autonomnog plovnog objekta" de lege ferenda određenog kao napredni pomorski objekt koji je pritom također (C): pomorski objekt.

Istovremeno, obilježja autonomnosti beznačajna su za plutajući objekt i nepomični odobalni objekt jer za njih nema prirodne, ali ni funkcionalne potrebe da budu autonomni budući da su fiksirani na jednom mjestu (npr. ponton, odnosno most). S druge strane, ronilice i drugi napredni pomorski objekti nalaze se izvan dometa plovnih objekata jer nisu plovni objekti, već napredni pomorski objekti za koje vrijedi samo posebno formulirani set pravila koji uređuje materiju vezanu za svojstvo autonomnosti i daljinske upravljivosti. Naravno, za njih će vrijediti i sva ona pravila koja vrijede za sve pomorske objekte općenito, dakako izuzev onih glede kojih se primjena izrijekom isključi.

Jednako tako, bit će regulirane i autonomne varijante plovnih objekata, konkretno autonomni brodovi za koje će vrijediti sva pravila koja inače vrijede za brodove uz poseban set pravila koja se nadovezuju na robotičku infrastrukturu broda, odnosno njegovo svojstvo autonomnosti i to posredstvom upravo pravila koje uređuje autonomni plovni objekt kao napredni (pomorski) objekt. Dakako, tamo gdje primjena konvencionalnih pravila nije prikladna za autonomne brodove, izrijekom će se takva primjena isključiti. Nasuprot njima, konvencionalni brodovi i ustaljeni pravni okvir PZ-a u ovako koncipiranoj strukturi pravila neće biti uzurpirani novim pravilima.

U svjetlu navedenog, a kao dodatan argument izloženom, zanimljivo je promotriti kretanje de facto broda unutar različitih pravnih kategorija ovisno ispunjava li pravne kriterije odgovarajućih definicija. Naime, oduzme li se de facto 
brodu sposobnost za plovidbu, on postaje boatel, ${ }^{80}$ odnosno plutajući objekt, a pridoda li se konvencionalnom brodu pored standardne sposobnosti za plovidbu i dodatna tehnološka infrastruktura koja ga čini autonomnim, onda on postaje autonoman brod. Dakle, "autonomni plovni objekt" kao de lege ferenda "napredni pomorski objekt", predstavljao bi novu poprečnu pravnu dimenziju broda koji tako, pored toga što predstavlja "plovni objekt", može posredstvom svoje opće odlike "pomorskog objekta" konzumirati i istovremeno predstavljati i "napredni pomorski objekt" disponira li relevantnom tehnologijom. S druge strane, ronilica kao de lege ferenda "napredni pomorski objekt" ostaje samo unutar okvira svoje definicije i definicije "naprednog pomorskog objekta" te ni u kojem slučaju ne bi mogla biti "plovni objekt" budući da ne bi ničime bila određena kao objekt koji je ili bi mogao biti namijenjen plovidbi, što bi dakako vrijedilo i za sve ostale (u vidu primjene odgovarajućih pravila) "nepoželjne" objekte.

\section{PERSPEKTIVE PRAVA AUTONOMNOG BRODARSTVA U BLIŽOJ I DALJOJ BUDUĆNOSTI}

\subsection{Trostupanjski et plus sustav odgovornosti?}

Izložena definicija MASS-a i stupnjevi autonomije koje je IMO predstavio u svibnju 2018. godine trebali bi poslužiti daljem napredovanju postupka regulatornog ispitivanja koje se provodi unutar postojećeg sustava međunarodnog pomorskog prava, a u odnosu na autonoman brod. O važnosti prepoznavanja stupnjeva autonomnosti ukazao je i Lloyd's Register (dalje: LR) koji u svojim smjernicama izlaže sedam razina autonomnosti (autonomy level - AL), a one su:

- AL 0) Ručan/manualan - nema autonomne funkcije (Manual - no autonomous function)

- AL 1) Brodski sustav za podršku odlučivanja (On-ship decision support)

- AL 2) Sustav za podršku odlučivanja na brodu i izvan njega (On and off-ship decision support)

- AL 3) Aktivna involviranost čovjeka ("Active" human in the loop)

- AL 4) Involviranost čovjeka - operater/nadzornik (Human on the Loop - opearator/supervisory)

- AL 5) Potpuna autonomnost (Fully autonomous)

- AL 6) Potpuna autonomnost (Fully autonomous); pritom je razlika između posljednje dvije razine u tome što kod AL 6) ne postoji nikakav nadzor, čak ni onaj povremeni, što nije slučaj na razini AL 5) jer na takvoj razini postoji barem nekakvo nadziranje rada premda rijetko. Nasuprot tome, kod AL 6) dakle ne postoji ni takvo nadziranje. ${ }^{81}$

80 Izraz za objekt koji prima facie predstavlja brod, ali istovremeno i hotel.

81 Lloyd's Register, Cyber-enabled ships: ShipRight procedure - autonomous ships, First edition, July, 2016, p. 2. 
Kako se ranije istaknulo, premda su stupnjevi autonomije naizgled bespredmetni kada je u pitanju definiranje i sistematizacija "naprednih pomorskih objekata", a otud i autonomnih brodova, ona je bespogovorno važna u sagledavanju pitanja odgovornosti i naknade štete koja može nastati korištenjem ovakve vrste napredne tehnologije. Primjeri kakve nalazimo na strani IMO-a ili LR-a svakako bi mogli poslužiti kao dobra teoretska baza za neku buduću regulativu.

$\mathrm{U}$ tom smislu, bilo bi od koristi institucionalizirati određene razine, odnosno nivoe autonomnosti s jedne strane, i stupnjeve odgovornosti koji bi se proporcionalno nadovezali na njih, s druge. Po autorovu mišljenju, uzor bi se možda mogao pronaći u modelu odgovornosti kakav nalazimo u "Atenskim pravilima". ${ }^{82}$ Dakle, primjena nekog sustava dvostupanjske odgovornosti, odnosno u slučaju autonomnih brodova, i više. Kako god, dodjeljivanje razine autonomnosti, kako i sam LR drži, biti će i jest složena odluka koja mora prepoznati tehničku izvedivost i razinu rizika (ekonomskog, sigurnosnog) koju nalazimo na strani novih sustava u odnosu na razinu rizika manualnog (ručnog) sustava, pritom ujedno uzimajući u obzir i zakonska ograničenja. ${ }^{83}$

\subsection{Kvazipomorci?}

Prema najnovijim statističkim prognozama, do 2025. godine na svjetskim trgovačkim flotama bit cee potrebno dodatnih 147.500 časnika. ${ }^{84}$ Naravno, s autonomnim brodovima ante portas očekuje se smanjenje potražnje za pomorcima u brojevima 30.000 - 50.000 ako i kada se bude odgovarajući broj potpuno autonomnih i poluautonomnih brodova upotrijebio u budućnosti. ${ }^{85}$

Nasuprot tome, iako primjena nove tehnologije ima tendenciju pojaviti se kao neka vrsta prijetnje toj vječnoj profesiji, prijetnja se sama po sebi više održava u smislu promjene pomoračke profesije, kao i u stvaranju nove. Naime, iako se može očekivati smanjenje potražnje, s druge strane očekuje se povećana potreba za visokokvalificiranim daljinskim operaterima i drugim sličnim varijacijama poput tzv. riding gangs, odnosno grupe radnika, koji nisu kvalificirani pomorci, a zaposleni su na brodu za obavljanje poslova bilo koje posebne ili opće namjene. Uz ovo, i nova vrsta pilota zasigurno će biti potrebna za održavanje brodova u radu. ${ }^{86}$

Na nadzor kao i možebitno preuzimanje kontrole nad brodom putem kontrolnog centra, odnosno stalne službe na kopnu već se u radu skrenula pozornost pa je

82 Naziv za Atensku konvenciju o prijevozu putnika i njihove prtljage morem od 1974. s popratnim protokolima - posljednji među njima od 2002. godine.

83 Lloyd's Register, loc. cit.

84 BIMCO / ICS Manpower Report 2015 (Executive Summary), http://www.ics-shipping.org/freeresources/manpower-report-2015. (17. VIII. 2019.), p. 13.

85 ICS, Seafarers and digital disruption: The effect of autonomous ships on the work at sea, the role of seafarers and the shipping industry, a study by HSBA Hamburg School of Business Administration, 2018, http://www.ics-shipping.org/docs/default-source/resources/ics-study-on-seafarers-and-digitaldisruption.pdf?sfvrsn=3, (17. VIII. 2019.), p. 19.

86 Loc. cit. 
nepotrebno posebno isticati kako će biti potrebno dobro sagledati na koji način će se oformiti set pravila koja bi regulirala pitanja djelatnosti takvih entiteta, kao i statusa osoblja koje bi u njima djelovalo, uključujući njihova prava, obveze i dužnosti. Po autorovu mišljenju, ovo predstavlja posebno kompleksnu pravnu, ali i organizacijsku problematiku jer je riječ o posve novom entitetu u sektoru pomorstva. Stoga bi po pitanju normiranja materije koja se odnosi na posebnosti kvazipomoraca, a osobito obalnih kontrolnih centara, bilo najbolje pristupiti zasebnim setom pravila.

U prilog ovome treba reći kako je 2019. Europska agencija za pomorsku sigurnost (EMSA) Hrvatskoj za potrebe nadzora teritorijalnog mora i Zaštićenog ekološkog ribolovnog pojasa (ZERP) stavila na raspolaganje sustav bespilotnih letjelica koji je bio predviđen da djeluje pod upravom Nacionalne središnjice za usklađivanje traganja i spašavanja na moru (Rijeka) te hijerarhijski niže podsredišnjice - Lučkoj kapetaniji u Splitu. Premda su se izvorno centri za upravljanje i nadzor trebali nalaziti u Puli, Rijeci, Zadru i Splitu, upravo ovaj primjer navodi se iz razloga što bi se na njemu mogao razvijati sustav potreban za nadzor i upravljanje autonomnih brodova s kopna, a od strane posebno educirane stalne službe.

\subsection{Pravilnik u začetku?}

Konačno, iskorak IMO-a nesumnjivo je i znak svjetskoj zajednici, odnosno državama članicama da u koraku s vremenom i najnovijim trendovima počnu ozbiljnije razmatrati fenomen autonomnog brodarstva. Pritom je IMO odobrio početni skup pravila za provođenje pokusne plovidbe i testiranja autonomnih brodova čime je otvorena mogućnost za stvaranje na nacionalnoj razini i prvih (preliminarnih) pravila koja se odnose na autonomne brodove.

Stoga, ako se postavi pitanje koji je ratio uvođenja nove kategorije plovnog objekta u hrvatsku pomorskopravnu nomenklaturu, to bi bio prvi razlog. Drugi razlog bio bi daljnji razvoj, odnosno početak istraživanja predmetnih tehnologija i na tragu s tim donošenje novog pravilnika koji bi podrobnije regulirao autonoman plovni objekt kako je definiran prema čl. 5, st. 1., t. 1. PZ-a.

Prema izjavi voditelja Službe Uprave sigurnosti plovidbe Ministarstva mora, prometa i infrastrukture RH (dalje: Ministarstvo) g. Z. Seidela danoj na Blue-Green Hub Forumu ${ }^{87}$ 6. ožujka 2019. u Zagrebu, daje se zaključiti da će prvi budući propis, kojim će se urediti upravnopravna materija autonomnog broda, biti za potrebe istraživanja i razvoja (I\&R), čime bi se trebao stvoriti okvir za testiranje ove nove vrste plovila i izvođenja pokusne plovidbe. Novim pravilnikom trebala bi se riješiti pitanja provedbe pokusne plovidbe, odnosno preduvjeta potrebnih kako bi se omogućio pristup takvim postupcima. Na tragu toga, pravilnik bi trebao riješiti i pitanja povezana s uspostavom "testnog polja" na moru, te bi trebao definirati koja bi državna tijela, odnosno javnopravna tijela bila involvirana u ishođenju odobrenja.

87 "Istraživanje i razvoj u Plavom sektoru I. dio: Izazovi i perspektive u brodogradnji i plovnom prijevozu" pod pokroviteljstvom Ministarstva mora, prometa i infrastrukture RH. 
Pravilnikom bi se ujedno propisivale dužnosti, ali i ovlasti u provođenju nadzora nad i tijekom pokusa.

Povrh toga, prema danim informacijama, javnopravno tijelo koje bi u smislu sigurnosti plovidbe sudjelovalo i surađivalo u etabliranju pravnog okvira za I\&R autonomnih brodova, jesu nadležna Lučka kapetanija, VTS (Vessel Traffic Systems) služba te priznata organizacija ovlaštena za obavljanje statutarne certifikacije pomorskih objekata.

$\mathrm{S}$ druge strane, osoba koja bi poduzimala pokusne plovidbe i testiranja s autonomnim brodovima, bila bi u obvezi osigurati sve uvjete sigurnosti plovidbe koje naloži nadležna Lučka kapetanija, prilikom kojih testiranja bi autonomni brod bio neprekidno praćen od strane VTS službe. U ovom bi slučaju svakako trebalo uspostaviti i odgovarajuće hitne postupke bude li, primjerice, došlo do kakvih kvarova ili pak prekida u komunikacijskoj vezi s autonomnim plovilom.

Ispitivanje, odnosno testiranje uključivalo bi odlazak broda, plovidbu i dolazak broda u matičnu luku, tj. luku polaska.

Konačno, testno polje određivalo bi se od slučaja do slučaja, za svaki pojedinačni projekt za određeno vremensko razdoblje. Slijedom navedenog, može se čak zaključiti kako bi se izdavanje odobrenja za provođenje testiranja s autonomnim brodom, a za potrebe I\&R vršilo per analogiam davanja koncesije, uzimajući pritom u obzir upotrebljivost morskog prostora i njegovu svrhu. Testna polja bi tako bila uspostavljena u odgovarajućim područjima mora, koja bi se kao takva svakako trebala nalaziti izvan aktivnih plovnih putova, područja povećane gustoće pomorskog prometa, zaštićenih ekoloških područja i područja u kojima se nalaze bilo kakve prepreke i instalacije bilo koje vrste.

\subsubsection{Individualizacija broda}

Kao nešto što u panel-diskusiji pri Blue-Green Hub Forumu nije bilo adresirano, valjalo bi svakako promotriti i neka moguća rješenja individualizacije autonomnog broda. Primjerice, možda bi u tom pogledu mogla poslužiti pravila najbolje prakse (eng. Code of Practice) koja su rezultat dosadašnjeg istraživanja MAS regulatorne skupine (MASRWG) čiji zadatak je, uz istraživanje problematike vezane uz siguran rad ovakvih sustava, bio i formulirati regulatorni okvir koji bi mogao biti usvojen od strane država, kao i međunarodnih tijela odgovornih za reguliranje mora i povezanih djelatnosti.

Naime, prema navedenim pravilima, predlaže se da obje strane plovila budu označene sljedećim podacima: ime operatera, broj telefona operatera (s međunarodnim pozivnim brojem), elektronička pošta operatera i oznaka opasnih stvari (engl. hazardous goods) odnosno oznaka opasnog materijala, tzv. hazmat 
lable.$^{88}$ Ovakva preporuka može svakako biti od koristi kao dobra baza za formiranje nekih rješenja dalje u budućnosti.

$$
* * *
$$

Za kraj, premda je nesporno da će široki spektar propisa biti potrebno višemanje prilagoditi za potpunu aklimatizaciju autonomnih brodova, koliko ce toga zapravo biti potrebno najbolje se održava u paragrafu 27. EU Rezolucije. Naime, iako se paragraf 27. odnosi na automobilska vozila, EU Rezolucija ipak sagledava relevantnu tehnologiju u širem smislu budući da u okviru termina autonomna vozila podrazumijeva sve vrste daljinski upravljanog, automatiziranog, umreženog i autonomnog cestovnog, željezničkog, vodenog i zračnog prijevoza, uključujući vozila, vlakove, plovila, trajekte, zrakoplove, bespilotne letjelice, kao i sve buduće oblike razvoja i inovacija u tom sektoru. ${ }^{89}$ Stoga za potrebe autonomnog broda paragraf 27. EU Rezolucije može ponuditi neke ideje o tome što se može očekivati na regulatornom planu. Dakle, relevantan paragraf navodi da će prelazak na autonomna vozila imati učinak na aspekte kao što su sigurnost na cestama i zapošljavanje (npr. otvaranje i gubitak radnih mjesta, obuka vozača teretnih vozila za rukovanje automatiziranim vozilima).

U svjetlu toga, jednako se može zaključiti kako će prelazak ili bar djelomična uporaba autonomnih brodova također utjecati na određene aspekte sigurnosti plovidbe, gubitak radnih mjesta, otvaranje novih radnih mjesta prilagođenih novoj tehnologiji, kao i obuku pomoraca za rukovanje visokoautomatiziranim brodovima. $\mathrm{U}$ okviru istog paragrafa također se naglašava da će biti potrebna znatna ulaganja $u$ cestovnu i energetsku infrastrukturu te $u$ infrastrukturu povezanu s informacijskim i komunikacijskim tehnologijama, pa se bespogovorno može zaključiti da će jednaka ulaganja biti potrebna i u slučaju autonomnih brodova, ako ne i zahtjevnija. ${ }^{90}$

Konačno, prelazak na autonomna vozila imat će učinak i na građanskopravnu odgovornost (odgovornost i osiguranje), sva pitanja povezana s okolišem (npr. energetska učinkovitost, korištenje obnovljivih tehnologija i izvora energije), pitanja povezana s podacima (npr. pristup podacima, zaštita podataka i privatnosti, dijeljenje podataka), pitanja povezana $\mathrm{s}$ infrastrukturom informacijsko-komunikacijske tehnologije (npr. velika koncentracija učinkovite i pouzdane komunikacije) ${ }^{91}$ Stoga se analogno može zaključiti isto i za potrebe autonomnih brodova.

Ako je očekivati eventualnu metamorfozu pomorskog prava kroz koju će ono proći, onda je pojava lex specialis konkretno za ovu materiju pod nekakvim nazivom The law of unmanned merchant shipping, odnosno pravo autonomnog brodarstva - vjerojatna.

88 UK Marine Industries Alliance, Being a Responsible Industry - An Industry Code of Conduct, Maritime Autonomous Systems (Surface) MAS(S), http://asvglobal.com/wp-content/uploads/2016/03/ UK-MIA-MAS-CoC-2016.pdf, (15. XI. 2016.), p. 14.

${ }^{89}$ Rezolucija Europskog parlamenta o pravilima građanskog prava o robotici (2015/2103(INL)) od 16. veljače 2017., para. 24.

90 Vidi supra, 4. 2.

91 Rezolucija Europskog parlamenta o pravilima građanskog prava o robotici (2015/2103(INL)) od 16. veljače 2017., para. 27. 


\section{OSVRT UMJESTO ZAKLJUČKA}

Uvođenjem u Pomorski zakonik nove kategorije "autonomnog plovnog objekta" koji je pritom određen kao "plovni objekt", nije se zapravo ništa posebno učinilo doli preuranjeno uvela mogućnost postojanja autonomnog broda te su se izazvale određene dileme. Ako je svrha uvođenja nove vrste plovnog objekta bila zbog potrebe daljnjeg razvoja relevantne tehnologije, onda se novouvedeni pojam trebao, ako išta, za početak označiti kao posebna vrsta broda, a onda možda alternativno i kao posebna kategorija pomorskog objekta ili nekog drugog privremenog "testnog" objekta jer bi se tako izbjeglo nepotrebno stvorene nedorečenosti.

Nejasno je zašto je zakonodavac novouvedeni objekt odredio kao "plovni objekt" ako je svrha njegova uvođenja bila isključivo za potrebe I\&R autonomnog brodarstva. Ako se ipak nastojala uvesti mogućnost postojanja autonomnog broda - što se zapravo, na neki način, uspjelo - to se onda moglo i izrijekom, a ne posredstvom nekih općih pojmova. Kako stoji, izgleda da bi bolji ishod bio, čak i kada je u pitanju I\&R, da se prilikom novih izmjena po pitanju autonomnog broda ostalo posve suzdržano.

Naime, definicija, kako je stilizirana i načinom na koji je uvedena, zoran je odraz negodovanja zakonodavca da uvede novu vrstu plovnog objekta. Naime, vođen uputom IMO-a koja se izrijekom odnosi isključivo na autonomne brodove, odnosno MASS, s jedne strane, i rješavanje problematike autonomnih ronilica, $s$ druge strane, zakonodavac se izgleda odvažio na nezgrapnu implementaciju novog pojma koji nalikuje lošem kompromisu između dvije krajnosti, dakle, ili uvođenja autonomnog broda ili neuvođenja ikakve pravne koncepcije takvog plovila.

Kratka rekapitulacija mogućnosti koje je zakonodavac mogao primijeniti jesu: (a) kreirati definiciju fokusirajući se na pojam broda te stvarajući pritom novu vrstu broda per analogiam nuklearnog broda; ili (b) novopredstavljeni pojam podvesti pod kategoriju "pomorskog objekta" i odrediti ga kao takvim.

S druge strane, pođe li se od pozadine I\&R autonomnog plovnog objekta, onda je u tom dijelu iskorak razumljiv i nadasve pohvalan. Naime, Hrvatska ima jedan vrlo jasan problem, a to je manjak domaće proizvodnje i konkurentnosti. Pored toga, kada se sa stajališta primjerice brodogradnje sagleda činjenice da je ona, premda posebna industrija u odnosu na brodarstvo, ipak s njom povezana i stoga receptivna na odgovarajuće ciklične promjene i volatilnosti na tržištu, kao i nezanemariva činjenica kineskog prevladavajućeg udjela na tom tržištu, onda je sasvim jasno da je u hrvatskom slučaju potreban neki zaokret koji bi pridonio konkurentnosti, a time i dugoročnoj održivosti. Naime, iskorak koji je učinjen u pogledu razvojnih prilika autonomnih plovnih objekata može se smatrati vrijednim doprinosom daljoj mogućnosti proliferacije znanja i inovativnosti u toj domeni, a otud razvoja novih usluga i proizvoda. Ovo bi, uz privlačenje stranih istraživača i projekata, trebalo biti nešto što bi blagotvorno djelovalo i na domaću brodogradnju. Naravno, samo ako ista uspije prepoznati potencijal uslijed kojeg se treba odvažiti na nove fronte i pri tome ustrajati. 
Tendencija stranih brodograditelja danas je imanje u fokusu svoga poslovanja sve više tehnologiju autonomnog brodarstva. Stav o tome kako bi na isti način trebala razmišljati i hrvatska brodogradnja, iskazan je i tijekom Blue-Green Hub inovacijske konferencije na temu Nove tehnologije u plavom sektoru: zelene inovacije u hrvatskoj brodogradnji, održanoj 17. listopada 2019. g. u Zagrebu.

Pored opće prirode brodograđevne industrije i već odavno prepoznate probleme koji tište hrvatsku brodogradnju, razvojem novih tehnologija ti problemi će se s vremenom samo još više amplificirati. U cilju izbjegavanja daljnjih turbulentnosti koje su - u svjetlu novih tehnoloških pomaka - i ovako neizbježne, nekoliko stručnjaka naglasilo je potrebu hrvatske brodogradnje da preispita svoje poslovanje u svrhu jačanja konkurentnosti i daljnje održivosti. Mišljenje je to i inženjera dr. sc. B. Ružojčića koji je i sam skrenuo pozornost na mogućnost, ali i potrebu hrvatske brodogradnje da se okrene proizvodnji specijaliziranih plovila.

U duhu nade koja se pronalazi u sektoru male brodogradnje, kao i u eventualnom (najavljenom) brodogradilištu specijaliziranom za proizvodnju luksuznih jahti u Dalju, možda bi i hrvatski nekadašnji giganti (osobito uslijed recentnih događaja) pronašli inspiraciju te sagledali mogućnosti promjene ili oplemenjivanja svoje ponude usmjeravanjem proizvodnje, po uzoru na Fincantieri ili Perini Navi, na jahte i megajahte ili na neka specijalizirana plovila. Na tom tragu, trebalo bi na hrvatskoj pameti, tradiciji i nekadašnjoj slavi hrvatskih brodogradilišta, stvoriti i plasirati ponovno jedan jaki hrvatski brodograditeljski brand koji bi svoju nišu unutar industrije brodogradnje zauzeo u području visoke tehnologije autonomnog brodarstva i specijaliziranih plovila.

\section{POPIS LITERATURE}

\section{Knjige, časopisi, znanstveni radovi}

1. Ćorić, D.; Pajković, M., "Autonomni brod - nova vrsta broda u pomorskom zakonodavstvu", Zbornik radova 2. Međunarodne znanstvene konferencije iz pomorskog prava - Suvremeni izazovi pomorske plovidbe (ISCML), Pravni fakultet Sveučilišta u Splitu, Split, 2018.

2. Pajković, M., Da li brod dron ulazi u pojam broda prema hrvatskom pomorskom pravu?, diplomski rad, Pravni fakultet Sveučilšta u Rijeci, Rijeka, 2017.

3. Vojković, G.; Milenković, M., "Autonomous ships and legal authorities of the ship master", Case Studies on Transport Policy, https://doi.org/10.1016/j.cstp.2019.12.001.

4. Vojković, G.; Milenković, M., "Novi pravni okvir i klasifikacija autonomnih, daljinski upravljanih i srodnih brodova", Zbornik radova 2. Međunarodne znanstvene konferencije iz pomorskog prava - Suvremeni izazovi pomorske plovidbe (ISCML), Pravni fakultet Sveučilišta u Splitu, Split, 2018.

5. Van Hooydonk, E., The law of unmanned merchant shipping-an exploration, Lawtext publishing limited, 20 JMIL, 2014.

6. Seipel, P., Law and Information Technology Swedish Views, An anthology produced by the IT Law Observatory of the Swedish ICT Commission, Information and Communication Technology Commission Report, Stockholm, 2002. 
7. Greenstein, S., Our Humanity Exposed, Predictive Modelling in a Legal Context, Stockholm University 2017.

8. Lexis PSL TMT Team, An Introduction to Technology Law, LexisNexis UK, 2018.

9. Murray, A., Information Technology Law - Law \& Society, Oxford University Press, 2019.

10. Calo, R.; Froomkin, A. M.; Kerr, I., Robot Law, Edward Elgar, 2016.

11. Callaghan, V.; Miller, J.; Yampolskiy, R.; Armstrong, S. (Ed.), The Technological Singularity: Managing the Journey, 1st edition 2017.

12. Norris, A., Legal Issues Relating to Unmanned Maritime Systems Monograph, published on-line, U.S. Naval War College, International Law Department, 2013.

13. Jakaša, B., Udžbenik plovidbenog prava, Narodne novine, Zagreb, 1979.

14. Smierzchalski, R., Intelligent Marine Control Systems, Enhanced Methods in Computer Security, Biometric and Artificial Intelligence Systems, Springer US, 2005.

15. Tomas, V.; Šegulja, I.; Vlačić, M., Osnove automatizacije, Pomorski fakultet u Rijeci, Sveučilište u Rijeci, Rijeka, 2010.

16. Radionov Radenković, N.; Mandžuka, S., "Autonomne podvodne ronilice: novi pojam hrvatskog pomorskog prava", Poredbeno pomorsko pravo, Vol. 46, No. 161, 2007.

\section{Propisi i druga dokumentacija}

1. Autonomous ship 'Yara Birkeland' - how far has the industry reached?, https:// www.dnmf.no/Artikler/SiteAssets/Sider/Arbeidet-i-ITF-med-autonome-skip/ Autonomous $\% 20$ ship $\% 20$ Yara $\% 20$ Birkelnad $\% 20$ how $\% 20$ far $\% 20$ has $\% 20$ the $\% 20$ industry\%20reached.pdf (9. III. 2019.).

2. CML, Maritime Unmanned Navigation through Intelligence in Networks (MUNIN), D9.3: Quantitative Assessment, European Commission, 2015.

3. MUNIN, Seventh Framework Programme, D7.2: Legal and Liability Analysis for Remote Controlled Vessels.

4. MUNIN, European Commission, D8.8: Final Report: Shore Control Centre.

5. Lloyd's Register, Cyber-enabled ships: ShipRight procedure - autonomous ships, First edition, July, 2016.

6. BIMCO / ICS Manpower Report 2015 (Executive Summary), http://www.icsshipping.org/free-resources/manpower-report-2015, (17. VIII. 2019.).

7. ICS, Seafarers and digital disruption: The effect of autonomous ships onthe work at sea, the role of seafarers and the shipping industry, a study by HSBA Hamburg School of Business Administration, 2018, http://www.ics-shipping.org/docs/defaultsource/resources/ics-study-on-seafarers-and-digital-disruption.pdf?sfvrsn=3, (17. VIII. 2019.).

8. UK Marine Industries Alliance, Being a Responsible Industry - An Industry Code of Conduct, Maritime Autonomous Systems (Surface) MAS(S), http://asvglobal.com/ wp- content/uploads/2016/03/UK-MIA-MAS-CoC-2016.pdf, (15. XI. 2016.).

9. Pomorski zakonik, Narodne novine, br. 181/04, 76/07, 146/08, 61/11, 56/13, 26/15, $17 / 19$. 
Moreno Pajković, mag. iur.: Iz antologije tehnologijskog prava: autonomni brod i drugi napredni objekti.. Zbornik radova Pravnog fakulteta u Splitu, god. 58, 3/2021, str. 875-906

10. Pravilnik o brodicama, čamcima i jahtama, Narodne novine, br. 13/2020.

11. California Vehicle Code, As Recodified and Reenacted by the 1959 Regular Session of the Legislature and as Amended to the Close of the 2014 Regular Session (CVC), California Legislative Information.

12. Rezolucija Europskog parlamenta o pravilima građanskog prava o robotici. (2015/2103(INL)) od 16. veljače 2017.

13. Prilog Rezoluciji Europskog parlamenta od 16. veljače 2017. s preporukama Komisiji o pravilima građanskog prava o robotici (2015/2103(INL)).

14. International Maritime Organization (IMO), https://www.imo.org/.

15. Ministarstvo mora, prometa i infrastrukture Republike Hrvatske, https://mmpi.gov. $\mathrm{hr} /$.

\section{FROM THE ANTHOLOGY OF TECHNOLOGY LAW: THE AUTONOMOUS SHIP AND OTHER ADVANCED OBJECTS WITHIN THE NEW MARITIME CODE - DE LEGE PONDERANDA}

With the aim of making the Croatian flag attractive to foreign vessels, the Croatian legislator passed on February 8, 2019, a decision on the promulgation of the Act on Amendments to the Maritime Code as part of the Maritime Legislative Reform Package. In addition to amendments related to vessel registration, in particular its digitization and the unification of its data, the amendments include a statutory standardization of the yacht and recreational boat charter contracts, as well as solutions related to the prevention of pollution of the sea. The amendments include changes in the field of maritime labour law as well. However, the amendments also include certain changes to the maritime-legal nomenclature, including therein the introduction of a new legal category - the autonomous waterborne object. The aim of this paper is therefore to analyse the position of such an object within the current maritime legal system of the Republic of Croatia and to consider a further trend in view of de lege ferenda, especially when autonomous ships are concerned. The paper also examines whether or not did the introduction of the new legal category in the Croatian Maritime Code directly and openly recognised autonomous ships and to what extent. In addition to this, the paper offers a new (additional) classification with regards to technological advances and trends. The recommendation offered thereat is built directly upon the existing maritime-legal nomenclature providing likewise a suitable nomotechnical solution in regulating the new types of objects in general, without substantially interfering in the existing content of the Croatian Maritime Code as originally conceptualized.

Key words: autonomous waterborne object, Croatian Maritime Code, autonomous ship, advanced maritime objects, autonomous merchant shipping, technology law, maritime-legal nomenclature 